IZA DP No. 8163

Testing an EU-Candidate's Place on the Maps of Global Economic, Political and Social Values: The Case of Turkey

Arno Tausch

Almas Heshmati

April 2014 


\title{
Testing an EU-Candidate's Place on the Maps of Global Economic, Political and Social Values: The Case of Turkey
}

\author{
Arno Tausch \\ Innsbruck University and \\ Corvinus University of Budapest \\ Almas Heshmati \\ Jönköping University \\ and IZA
}

Discussion Paper No. 8163

April 2014

IZA

P.O. Box 7240

53072 Bonn

Germany

Phone: +49-228-3894-0

Fax: +49-228-3894-180

E-mail: iza@iza.org

\begin{abstract}
Any opinions expressed here are those of the author(s) and not those of IZA. Research published in this series may include views on policy, but the institute itself takes no institutional policy positions. The IZA research network is committed to the IZA Guiding Principles of Research Integrity.

The Institute for the Study of Labor (IZA) in Bonn is a local and virtual international research center and a place of communication between science, politics and business. IZA is an independent nonprofit organization supported by Deutsche Post Foundation. The center is associated with the University of Bonn and offers a stimulating research environment through its international network, workshops and conferences, data service, project support, research visits and doctoral program. IZA engages in (i) original and internationally competitive research in all fields of labor economics, (ii) development of policy concepts, and (iii) dissemination of research results and concepts to the interested public.
\end{abstract}

IZA Discussion Papers often represent preliminary work and are circulated to encourage discussion. Citation of such a paper should account for its provisional character. A revised version may be available directly from the author. 


\section{ABSTRACT \\ Testing an EU-Candidate's Place on the Maps of Global Economic, Political and Social Values: The Case of Turkey}

Following the attempt by Alesina and Guiliano (2013) to measure global culture and to project these measurements onto real choropleth geographical world maps, we utilize the data from the World Values Survey (WVS) to arrive at robust measurement scales of global economic, political and social values and to assess Turkey's place on them. Our study, which is based on 92,289 representative individuals with complete data in 68 countries, representing $56.89 \%$ of the global population, looks at hard-core economic values in the countries. From our new nine dimensions for the determination of the geography of human values, based on a promax factor analysis of the available data, we use six factor analytical scores to calculate a new Global Value Development Index, which combines: avoiding economic permissiveness; avoiding racism; avoiding distrust of the army and the press; avoiding the authoritarian character; tolerance and respect; and avoiding the rejection of the market economy and democracy. Our results show that the five best ranked countries are all western democracies. Our global value development index ranks Morocco twelfth - just behind the USA. Turkey is ranked 25, ahead of several EU member countries. But there are still considerable deficits concerning the liberal values components, which are very important for effective democracy, and there are very large regional differences, confirming the dictum by Huntington (1996) about Turkey as a torn country. The deficits suggest that the Turkish state, Turkish civil society and European decision makers would be well advised to continue to support civil society and secular democracy in Turkey.

JEL Classification: C43, F50, Z12, D73

Keywords: index numbers and aggregation, international relations, international political economy, religion, bureaucracy, administrative processes, corruption

Corresponding author:

Almas Heshmati

Department of Economics

Jönköping University

Box 1026

SE-551 11 Jönköping

Sweden

E-mail: almas.heshmati@gmail.com 


\section{Introduction}

Whatever way, the European Union (EU) candidate Turkey's internal and external developments will sharply divide opinions around Europe and beyond (Clesse and Tashan, 2004). And whatever way, the scientific study of opinion and value structures and processes in the context of EU enlargement in Turkey, the other candidate countries and in the EU-28 and beyond are an absolute necessity. Following the new attempt by Alesina and Guiliano (2013), to measure global culture and to project these measurement scales onto real choropleth geographical world maps, we also utilize the freely available data from the World Values Survey (WVS) at the University of Michigan ${ }^{1}$ to arrive at such robust and similar measurement scales of global economic, political and social values and we attempt to place Turkey on them. The contribution by Alesina and Guiliano (2013) is such an important study for this moment in Europe, because it allows social science to make solid and scientific judgments, where usually only prejudice against or in favor of Turkey's hotly contested EUaccession prevails. And whatever the shortcomings of our analysis may be, our attempt should be judged at the end of the day by the methodological innovation it attempts.

Our central question in this essay is thus what is Turkey's place on realistic new maps of global values, given that the existing sociological cross-national value comparisons are insufficient? The aim of this essay is thus two-fold: to build such new global value maps, and to see what the implications for Turkey and its unhappy relationship with the EU are. The study will hopefully become not only a contribution to the academic debate on the subject, but also a useful tool for the decision makers in international politics. The methodology put forward here can also help decision makers to assess the value structures in other EU enlargement candidate countries, and also can help the decision makers in other continents like Latin America or the ASEAN countries, or in international organizations, like the United Nations, the OECD, the World Bank etc. to arrive at sounder judgments about economic, social and political basic values, prevalent in a given country.

The systematic use of large-scale comparative international opinion data, above all from the $W V S$, which we undertake here, is not new and not anymore restricted to the sociological discipline. More and more, the economics discipline becomes aware of the enormous possibilities to address the contentious issues of culture in the economics of a global society, characterized more and more by migration and the globalization of world religions. Global value research, which originally grew out of the desire of large transnational corporations (i.e. IBM Corporation) to adapt to ever more complex and pluralistic cultural patterns of their clients and staff (Minkov, 2009; Minkov and Hofstede, 2011, 2013) by now is a longestablished social science discipline, and it is a pity how little the overall European public and especially the decision makers took notice about its results in the debate about Turkish EUaccession so far.

Sociology, for sure, did its "homework" and there are even attempts to arrive at realistic assessments of global Muslim and Arab Muslim opinion in a comparative perspective. Sociology, looking already back on a very long established tradition of the empirical sociology of religions, which dates back to the $19^{\text {th }}$ Century (Morel, 2003), contributed greatly over the last two decades towards understanding global Muslim opinion (Diez-Nicolas, 2007, 2010; Moaddel, 2002, 2003, 2008; Tessler, 2003, just to mention a few).

At this stage, the comparative social scientist and economist might wonder perhaps whether all the debate that rages on the issue under scrutiny here - i.e. Turkey's place as a European nation - is really well-informed by the evidence from quantitative social science on the subject. Turkey, the country of origin of around some $70 \%$ of the 3.5 million Muslims

\footnotetext{
${ }^{1}$ http://www.worldvaluessurvey.org/
} 
residing in Germany, ${ }^{2}$ from the early beginnings was an integral part of the WVS Project. The deficit of the European political debate to take into account the results of systematic social science research on the issue of Turkey is all the more depressing, since the systematic use of data from the WVS in advanced social science Turkish studies is now commonplace (Erișen, Erişen and Özkeçeci-Taner, 2013; Negrón-Gonzales, 2012; Sarigil, 2011; Şimşek, 2013; Yeşilada, 2002; Yeşilada and Noordijk, 2010).

Confronted by a European public debate, which is threatening to become "essentialistic" on both sides of the great "Turkish EU-membership divide", it is necessary to recall at the outset that for advanced research in the economics discipline, the question about the relationship between economics and religion is not new. The essay by Barro and McCleary (2003) is a good example of how today economic research uses data from the WVS Project to study the relationship between religion, denominations and economic growth. Alesina (2013); Alesina and Angeletos (2005); Alesina and Fuchs-Schündeln (2007); Alesina and Guiliano (2010, 2011, 2013); Alesina, Cozzi and Mantovan (2012); and Alesina, di Tella, and MacCulloch (2004) all show how the economic discipline can indeed gain hard-core, quantitative and valuable insights from comparative knowledge about such phenomena as generalized trust and social capital, individualism, family ties, morality, attitudes toward work and perception of poverty, and religious practice for economic processes. In this essay, we will attempt without hesitation to define "cultures" largely following Alesina and Guiliano (2013) on a global scale, and also in Turkey.

In our attempt to openly test the often unspoken but politically very relevant contention by many members of the European political class and the public at large that in the end Turkey does not really belong to Europe because it's a Muslim country ${ }^{3}$ (see below) by advanced international data and advanced quantitative methods, like Promax oblique factor analysis, we use 30 indicators from the WVS. Although some of our indicators are different from those used by Alesina and Guiliano (2013), there is lots of resemblance between the two approaches, and a high correspondence between the choropleth geographical maps of global values, presented by Alesina and Guiliano, and our own attempts will emerge. There are, nevertheless, some differences in the approach: we uniformly use promax oblique factor analysis to test the relationships between the value factors. Our chosen indicators represent the best available choice of WVS data in terms of interview coverage, and in addition, our results - in contrast to those reported by Alesina and Guiliano, also contain important social, economic and political background variables.

In the course of our research, we are going to present data not only at the national, but also at the regional level of the slightly less than 70 nations compared here, analyzing the factor analytical scores of our new nine global value indicators, derived from over 90.000 representative interviews across the globe and also in the Turkish regions, and we will compare their performance with those of all other regions of the world with available data and a sufficient number of reported WVS interview partners per region (i.e. $\mathrm{n}>30$ ). In that process we will discover the still existing deep regional value cleavages which exist in Turkey, benefiting the ruling conservative Islamist AKP, whose power-base is the urban and rural poor Turkish speaking Sunni Muslim majority population from Anatolia.

In designing this research project, we made the discovery that hitherto existing attempts in sociology to draw maps of human values across nations (i.e. Hofstede and Inglehart), valuable as they may be, are really still unsatisfactory in terms of country coverage, issue coverage and also methodologies used. Thus, besides background variables, like age, gender, education

\footnotetext{
${ }^{2}$ http://www.euro-islam.info/country-profiles/germany/

3 http://www.dw.de/turkey-not-fit-for-eu-accession-sarkozy/a-14875593
} 
level, life satisfaction, educational values, values of responsibility, general political attitudes on the left-right scale, identification with democracy, general social capital variables (trust in people, in the armed forces, in the Press) and religious attitudes, our study in particular looks at hard-core economic values, in all countries of the world with available data, namely:

1. Competition good or harmful (competition policy, admission of a free market)

2. Migration policy (prevent people from coming) (migration policy)

3. Important child qualities: hard work (attitudes towards work)

4. Justifiable: avoiding a fare on public transport (attitudes towards public services; limited morality)

5. Justifiable: cheating on taxes (tax evasion and shadow economy)

6. Justifiable: claiming government benefits even if one is not entitled to them (attitudes towards public services, work attitudes)

7. Justifiable: someone accepting a bribe (corruption)

8. Rejecting neighbors: immigrants/foreign workers (economic and social discrimination)

9. Neighbors: People of a different race (economic and social discrimination)

10. University is more important for a boy than for a girl (economic and social discrimination).

Fascinating relationships between the underlying factors, explaining these 30 variables, and which render themselves for objective and value-free comparisons will emerge, and we will also be able to name for each country of the world the exact position it has on those factors. We will be able to show the regional cleavages for those factors, and we will be able to say whether Turkey's population has attitudes which are different from or are similar to other current EU-candidate countries, like Macedonia. We will be able to judge whether in principle there exist really fundamental value differences between Turkey and the rest of Europe, disqualifying Turkey ex ante from EU membership - or not. These results will hold irrespective of recent political tendencies in the country, connected with the Gezi Park protest movement.

Rest of this study is organized as follows. Section 2 provides a general picture of Turkey ante portas. Section 3 discuss the political economy and sociology of global values. The overlooked role of the shadow economy in assessing global values is analyzed in Section 4. The methodology is outlined in Section 5. Section 6 is on re-analysis of Inglehart's data. The final factor analytical model is presented in Section 7 followed by the new choropleth maps of global human values in Section 8. In Section 9 we discuss regional value differences at the sub-national level and in the final Section Turkey - a Torn Country? Conclusions and Perspectives are presented.

\section{Turkey ante portas}

In our view, the culturalist "debate" about "Islam in Europe", focusing on "Islam as such" ("Islam an sich"), leaves no room for the legitimate concerns of those who indeed fear that the secular Republic established by Kemal Atatürk is progressively being undermined by a powerful and increasingly authoritarian political leadership, which so handsomely won yet another victory at the polls in 2014, all the protest movement in the major cities around Gezi Park notwithstanding. ${ }^{4}$ But this essay is not on Turkish internal politics, but, if you like, on comparative values "as such", regardless of one's stand in the often controversial and bitter cleavages now surfacing in Turkish society.

\footnotetext{
${ }^{4}$ http://www.gloria-center.org/2013/04/turkeys-regime-fails-abroad-is-world-champion-at-fundamentaltransformation-at-home/
} 
Many international observers, among them Toghill (2012), found that the real issues in Turkish accession indeed have nothing to do with legal criteria, economic requirements or international relations. The problem, Toghill argues, is really simply that of admitting a large Muslim country into the EU. But it's often forgotten that the then French overseas department of Algeria with a largely Muslim population was an integral part of the then "European Economic Community” from January $1^{\text {st }}, 1958$ right to July 5 ${ }^{\text {th }}, 1962$, the day when Algeria became independent. ${ }^{5}$ When Algeria joined the European Economic Community, no Copenhagen criteria were in place, and a bitter counter-insurgency war was being fought with tens of thousands of victims. So adherents of Turkey's EU-accession might say that Muslim Algeria as a colony with a bitter civil war was welcome as a European Economic Community member, but not Turkey.

With almost 30 years since the Turkish Republic's application to join the European Economic Community in 1987, and almost 20 years since the country was declared eligible to join the EU in 1997, the EU one way or the other, Europe will have to reach a decision ${ }^{6}$ how to proceed. Already in 1997 it was declared eligible to join the EU. Turkey's involvement with European integration dates way back to 1959 and includes the Ankara Association Agreement (1963) for the progressive establishment of a Customs Union (ultimately set up in 1995). ${ }^{7}$

Countries preparing to join the EU today are: Albania, Bosnia and Kosovo as potential candidates and Iceland, Macrdonia, Montenegro, Serbia and Turkey ${ }^{8}$ as official candidates. As a glance at the United States Central Intelligence Agency "World Factbook" will convince every reader of this article very quickly, ${ }^{9}$ these countries are characterized by the following Muslim share of population: Turkey (99.8\%), Albania (56.7\%), Bosnia and Herzegovina (40\%), Macedonia (33.3\%), Montenegro (19.1\%), and Serbia (3.1\%).

\section{The political economy and sociology of global values}

Alesina and Guiliano (2013) define culture to comprise measurable tendencies in the following variables: generalized trust, individualism versus collectivism, family ties, generalized vs. limited morality, attitudes toward work and perception of poverty and religion.

The most studied cultural trait, according to Alesina and Guiliano (2013) is the measure of generalized trust toward others. The importance of this trait cannot, as argued by Alesina and Guiliano, cannot be overemphasized. They mention that, every commercial transaction has within itself an element of trust; and economic backwardness in the world can following economist Kenneth Arrow, be explained precisely by the lack of mutual confidence. The WVS asks respondents around the globe: "Generally speaking, would you say that most people can be trusted or that you can't be too careful when dealing with others?" Nowadays, there is, Alesina and Guiliano highlight, a vast literature showing a close connection between trust and economic development. Generalized vs. limited morality are also, Alesina and Guiliano argue, relevant in fostering economic development. Limited morality exists where cooperative behavior is extended only towards immediate family members, whereas generalized morality exists where cooperative behavior is extended toward everyone in society.

\footnotetext{
${ }^{5}$ http://www.eui.eu/Research/HistoricalArchivesOfEU/News/2013/07-30EurafricaandDeGaullesConstantinePlan.aspx

${ }^{6}$ http://www.todayszaman.com/news-338454-merkel-reiterates-doubts-on-turkeys-eu-membership-but-supportstalks.html

${ }^{7}$ http://ec.europa.eu/enlargement/countries/check-current-status/index_en.htm

${ }^{8} \mathrm{http://ec.europa.eu/enlargement/countries/detailed-country-information/turkey/index} \mathrm{en.htm}$

9 https://www.cia.gov/library/publications/the-world-factbook/
} 
Among the most prominent competing international sociological attempts to define and measure the development of human values we should specify the current two major approaches dominating international social science: Hofstede's theory of global values and Inglehart's and his associates' studies of world values.

First we mention Geert Hofstede. This Dutch psychologist and his associates really stood at the beginning of comparative international value research. Initially, they based their empirical studies on global culture on the statistical analysis of the staff of the single US transnational enterprise IBM in 40 different countries around the world (see also Hofstede, 2001; Hofstede and Minkov, 2010; Hofstede, Hofstede and Minkov, 2010; Minkov and Hofstede, 2011, 2013). According to Hofstede and his school, there are four to six basic clusters of international value systems, and they are all defined along the scales of how different national societies handle ways of coping with inequality, ways of coping with uncertainty, the relationship of the individual with her or his primary group, and the emotional implications of having been born as a girl or as a boy. Hofstede defines these dimensions of national culture as: power distance, individualism vs. collectivism, masculinity versus femininity, uncertainty avoidance index, long-term orientation and indulgence versus restraint.

Between 1990 and 2002, Hofstede replicated these dimensions in six other cross-national studies on very different populations from consumers to airline pilots, covering between 14 and 28 countries. In the 2010 third edition of his book 'Cultures and Organizations: Software of the Mind', scores on the dimensions are listed for 76 countries. ${ }^{10}$ But - perhaps somewhat surprisingly for large sections of the European public, -the ranks of Turkey on the global Hofstede scales are absolutely unspectacular and are somewhere in the middle of global society based on sample of 62 countries: uncertainty avoidance index (18), power distance (25), indulgence versus restraint (27), individualism vs. collectivism (35), masculinity versus femininity (36) and long-term orientation (36). We only considered the countries with complete values for the final analysis.

Inglehart, in some of his main publications, developed by contrast an interpretation of global value change (Inglehart, 2003; Inglehart and Baker, 2000; Inglehart and Norris, 2003; Inglehart and Welzel, 2003, 2005), which rests on a well-known two-dimensional scale of global values and global value change, which is based on the statistical technique of factor analysis of up to over twenty key WVS variables from the originally more than 900 survey items on practically all major areas of human concern, from religion to politics to economic and social life. Factor analysis reduces variables to the underlying statistical dimensions, and is based on a mathematical procedure, implemented today on most advanced statistical software packages for social statistics, like IBM SPSS.

The two Inglehart dimensions (see Inglehart and Baker, 2000, pp. 23-24) are: (i) the Traditional/ Secular-Rational dimension and (ii) the Survival/Self-expression dimension. These two dimensions also explain more than 70 percent of the cross-national variance in a factor analysis of ten indicators, and each of these dimensions is strongly correlated with scores of other important variables. The factor scores generated by these 10 items listed previously are highly correlated with factor scores from his earlier research. In a statistical Table in that landmark article, Inglehart and Baker also show the results from a factor analysis of variables with 165,594 WVS respondents (Inglehart and Baker, 2000, Table 1). As expected, the factor loadings are considerably lower than those at the national level, and are reproduced here below. The traditional values are defined by: God is very important in respondent's life (0.70), it is more important for a child to learn obedience and religious faith than independence and determinations (0.61), abortion is never justifiable (0.61), respondent

\footnotetext{
${ }^{10} \mathrm{http}: / /$ www.geerthofstede.nl/dimensions-of-national-cultures
} 
has strong sense of national pride (0.60) and respondent favors more respect for authority (0.51). The self-expression values are defined by: respondent gives priority to self-expression and quality-of-life (0.59), respondent describes self as very happy (0.58), respondent has signed and would sign a petition (0.59), homosexuality is always justifiable (0.54) and you should be trusting people (0.44).

For Inglehart and his associates, the rise of rational-secular values is an important element in socio-economic and democratic development. Self-expression values, as opposed to survival values, give high priority to environmental protection, tolerance of diversity and rising demands for participation in decision making in economic and political life. For Inglehart, there is a dramatic shift in child-rearing values, from emphasis on hard work toward emphasis on imagination and tolerance as important values to teach a child in the course of socioeconomic development. Societies that rank high on self-expression values also tend to rank high on interpersonal trust. The culture of trust and tolerance are crucial to democracy. Secularism (y-axis) and self-expression (x-axis) are but two sides of the same coin modernity. The Inglehart School assumes the following global "map of human values". In our adaption of the famous Inglehart map, we highlight the position of Turkey on it. Assuming that self-expression values rise in parallel with secular-rational values, it is clear that Turkey's path corresponds to the "global path".

Insert Graph 1: Map of global human values according to Inglehart and associates (our own adaption) and the place of Turkey on it.

Our own calculations show that Tanzania, Puerto Rico and Jordan are the least secular countries of the world, while Sweden, Japan and the Czech Republic are the most secular countries of the world. Turkey's ranking needs a special comment here: while Turkey is more religious than most West European countries, it is as religious as the United States, Poland, and the Latin American democracies Chile and Brazil. Its rank 49 among the 66 countries is not sensational, replicating the earlier already mentioned tendency from Hofstede's surveys. New Zealand, Australia and the United States are the most self-expression oriented countries of the world, while all of the five most survival oriented and least self-expression oriented countries of the world were of Orthodox Christian cultural heritage: Moldova, Ukraine, Russia, Belarus and Romania. So Turkey is rank 45 on the global self-expression scale, regarded by Inglehart and his associates to be so vital for "effective democracy". Turkey is ahead of several countries of the EU, reminding our readers that self-expression values are defined by the priority to self-expression and quality-of-life, happiness, preparedness to sign a petition, tolerance vis-à-vis homosexuality, and trust in people. The results clearly suggest that the world of Christian Orthodoxy is the global region with the lowest self-expression values.

Our choropleth maps - Maps 1 and 2 - designed with Inglehart's data, further highlight these aspects of the Inglehart global map of human values. Generally, one refers to the "map of human values" nowadays in the context of the famous Graph, designed by Inglehart and his associates, shown in Graph 1 of this essay. However, the design of real choropleth maps, i.e. e. maps designed to show global statistics on an easily readable world maps, which simplify the global data range to up to nine, ten or eleven layers (high, medium, low) brings about important insights into the essence of social scientific theories, and - even at the price of oversimplification - try to show to the audiences confronted with these theories where a given phenomenon is strongest or weakest.

Insert Map 1: Inglehart: Secular Values. Data from the WVS waves 1-4 Insert Map 2: Inglehart: Self-Expression Values. Data from the WVS waves 1-4 
Inglehart and Baker (2000) also maintain that in traditional societies a main goal in life is to make one's parents proud and one must always love and respect one's parents, regardless of how they behave. Conversely, parents must do their best for their children even if their own well-being suffers. People in traditional societies idealize large families, and they actually have them. However, extensive evividence indicates that these values tap an intergenerational shift from an emphasis on economic and physical security toward an increased emphasis on self-expression, subjective well-being, and quality-of-life concerns. In contrast to the hitherto dominant explanations, we introduce the dimension of the shadow economy, acceptance of corruption, and overall moral decay (see also Schneider, 2005 Torgier and Schneider, 2007). And as we see in the results, this consideration of the dimension of economic permissiveness results in a significant redrawing of the global maps of human values.

\section{The overlooked role of the shadow economy in assessing global values}

It is clear that Hofstede and Inglehart neglected very important dimensions of economic and social life - the shadow economy, which is especially becoming more and more important in the process of the further enlargement of the EU. Let us just take one important example - the evaluation of a randomly picked current EU member candidate country, the Former Yugoslav Republic of Macedonia. The United States Department of States says in its country human rights report, issued in February 2014, referring to the government's failure to fully respect the rule of law, interfering in the judiciary and the media, and selective prosecution of political opponents, government corruption and police impunity, political interference, inefficiency, favoritism toward well placed persons, and corrupt judicial system.

Shadow economic activity has been on rise and causing violations of laws and regulations, lowering tax revenue collections, statistical discrepancies, inequality, corruption and public budget deficit and public debt problems for the state and its organizations. The shadow economy captures all the activities beyond measurement by official activity. In all countries, there is evidence that the shadow economy has a significant share of the overall economy. It is also labelled as hidden, black, underground, unobserved, unofficial, unrecorded, and parallel economies. The rise of the shadow economy around the world is attributed to the stronger presence of government activity, increase in tax rates, and the desire to escape taxes and regulatory restrictions. Tanzi and Schunecht (1997), Tanzi (1999), Schneider (2005), Eilat and Zinnes (2002), Ahumada et al. (2008) and Chaudhuri et al. (2006) shed light on the shadow economic activities, its measurement and development across developed, developing and transition economies.

There are several factors identified by researchers that are expected to have a negative association with the size of the shadow economy. These include trust (D'Hernoncourt and Meon, 2012), and tax morale and quality of institutions (Torgler and Schneider, 2009). Three key factors that their extent has impacted the size of shadow economy are: debt, default risk, corruption and financial development (Elgin and Uras, 2012; Blackburn et al., 2012), Information Communication Technologies (ICT) (Indjikian and Siegel, 2005) and environmental violations (Biswas et al., 2012).

The shadow economy is a key source of the gap between observable and actual economic measures. It captures all the activities beyond measurement by official activity and consists of both legal and illegal activities outside the reach of government. It makes up a significant share of the overall economy around the word. Other synonyms for the shadow economy are the hidden, black, underground, unobserved, unofficial, unrecorded, and parallel economies. There is evidence that underground activities have been on the rise since the 1970s. The rise is attributed to the stronger presence of government activity in the economies; the increase in tax 
rates to finance larger public spending programs, and in parallel, the desire to escape taxes and regulatory restrictions has gained prominence (Tanzi and Schunecht, 1997). Tanzi (1999) suggests that the shadow economy reaps because of the presence of activities that are difficult to measure and tax.

Schneider (2005) considers shadow economic activities a fact of life. Most societies attempt to reduce its magnitude by controlling activities through legal measures such as punishment and persecution or by preventive measures with investment in welfare and education. Despite significant investment in the collection of data on shadow economic activities, it is rather difficult to obtain accurate information about its nature and magnitude. Schneider mentions the existence of a comprehensive literature on particular aspects of the shadow economy, but the subject remains controversial. Furthermore, there is disagreement among researchers about the definition, estimation procedures and their use in economic analysis and policy making.

In a common approach, Schneider (2005) defines the shadow economy to include all marketbased legal production of goods and services that are deliberately concealed from public authorities for the following reasons: (i) to avoid payment of income, value added or other taxes, (ii) to avoid payment of social security contributions, (iii) to avoid having to meet certain legal labor market standards, and (iv) to avoid complying with certain administrative procedures. However, this definition does not include economic activities that are illegal and fit the characteristics of classical crime, as well as the informal household economy or tax evasion.

In another approach Eilat and Zinnes (2002) treat the shadow economy as a distinct entity, instead of seeing it just as a symptom of policy failures of the transition countries. They examine its short-term and dynamic consequences for development. The shadow economy is measured in two different ways: first, the electricity method which attributes growth in total electricity consumption in excess of growth in GDP to the shadow economy, and the second measure is a modified electricity approach correcting for limitations in the first approach.

Yet in a third approach, Ahumada et al. (2008) look at the monetary measure of the shadow economy where the money demand function, observed cash balances, and its variation which is explained by variables which induce agents to make hidden transactions is used to estimate the size of the shadow economy. However, on econometric grounds, researchers have criticized the quantitative accuracy of this method. The critique is attributed to time series properties, structural breaks and sensitivity to units of measurement to lag the dependent variable and its initial condition.

Limited statistics from high income countries point to a positive trend in shadow economic activities development, but yet little is known about its magnitude in transition, low-income and emerging economies. Schneider (2005) estimates the shadow economy for 110 countries (66 developing, 23 transition and 21 industrialized OECD) observed for 1990/1991, 1994/1995 and 1999/2000. The results provide some insights about the main causes and studies the dynamic effects of the shadow economy. The main causes of the shadow economy are found to be the tax and social security contribution burdens, the intensity of regulations and the low quality of public sector services.

The transition economies have undergone major changes. Increased unemployment, decline in GDP, a paralyzed bureaucracy and government corruption during this period saw a surge in the growth of shadow economic activities. Eilat and Zinnes (2002) conducted research on the shadow economy in transition countries. The objective was to use a policy perspective to find out whether shadow economy is a "friend" or a "foe". The research was conducted in three 
parts: it lays out the theoretical and empirical backgrounds, it estimates the size of the shadow economy, and it examines its effects and discusses issues of policy implementation.

For the empirical part, Eilat and Zinnes (2002) measures the relative size of the shadow economy to official GDP in 25 transition countries for the period 1990 to 1997. The patterns show that, once established, the shadow economy is hard to remove. Estimation results show that a dollar decline (rise) in official GDP is attenuated by a shadow economic expansion (contraction) of 31 (25) cents. Finally the authors examine whether the shadow economy prevents, slows down, or promotes economic growth and competitiveness, and through what mechanisms. In addition, they consider implications for policymaking that address the key questions. The policy recommendations include: actions with multiple benefits, actions that directly target the shadow economy, actions whose effectiveness is changed by the shadow economy, and implementation considerations.

Schneider (2005), in the context of industrialized and transition economies, mentions that the shadow economy is expected to influence the tax system and its structure, the efficiency of resource allocation between sectors, and the official economy in a dynamic sense. Therefore, several studies have integrated underground economies into macroeconomic models to facilitate investigation of the effects of monetary and fiscal policies on the formal and informal economies and economic growth. In the neoclassical view, the underground economy is assumed to provide the economy with dynamic entrepreneurial spirit. It can lead to greater competition and higher efficiency, help to create markets, increase financial resources, enhance entrepreneurship, and transform the legal, social, and economic institutions necessary for accumulation providing a higher potential for economic growth.

Schneider (2005) concludes that for all countries investigated, the shadow economy as share of GDP has reached a remarkably large size (Africa 33.9-41.2; Americas 34.2-41.5; Asia 20.9-26.3; Transition countries 31.5-37.9 and highly developed countries 13.2-16.8). The average percentage shares of GDP in all cases are increasing over time. The author demonstrates empirically a strong interaction of the shadow economy with government policies and with the official economy. He draws three further conclusions. First, an increasing burden of taxation and social security payments, combined with rising state regulatory activities, are the major driving forces underlying the size and growth of the shadow economy. Second, the shadow economy has a statistically significant and quantitatively important influence on the growth of the official economy. Increases in the shadow economy have a negative effect on the official growth in a developing country, but a positive effect in the developed industrialized and transition countries. Finally, shadow economies are a complex phenomenon, and are present in all types of economies. People engage in shadow economic activity because of government actions, most notably high levels of taxation and regulation.

There are several factors that are expected to have a negative association with the size of shadow economy. These include trust, tax morale, and quality of institutions. Some researchers, explaining the shadow economy, go beyond the objective variables such as the tax burden, rate of public expenditure, or the density of regulation, and use subjective variables such as perceptions, expectations, attitudes and motivations such as tax morale or institutional quality. The relationship between tax morale and institutional quality and the shadow economy is investigated by Torgler and Schneider (2009). The shadow economy is measured as a percentage of the official GDP. WVS/European Values Survey data on cheating on taxes and Latinobarometro data on the justifiability of avoiding paying taxes are measures of tax morale, and the quality of governance index is used as a proxy for institutional quality. They use a multivariate analysis to examine the quantitative impact of these factors on the level of and changes in the shadow economy. They find strong support for 
the hypothesis that higher tax morale and a higher institutional quality lead to a smaller shadow economy.

Another factor with significant potential impact on the size of shadow economy is trust. Trust can be a substitute to formal and legal contracts in a situation when the agents involved in shadow transactions cannot rely upon the formal legal system to enforce agreements or settle disputes. This view suggests that trust increases the size of the formal sector by negatively impacting the size of the informal sector. In this regard, D'Hernoncourt and Meon (2012) investigate the relationship between trust and the size of shadow economy. They report a negative relationship between the size of the shadow economy and generalized trust. The data include 145 countries from both developed and developing countries observed over the period 1999-2003. Trust is defined as the trust index provided in the WVS data. Comprehensive sensitivity analyses conducted confirm that the relationship is robust to controlling for various sets of factors. Trust and the shadow economy are negatively related and trust matters more for developing countries.

\section{Methodology}

Following the introduction of the meanwhile world-famous Human Development Index and its annual updates in the Human Development Report in recent years (see UNDP, 2013) a more rich literature on the quantitative measurement of development outcomes has been developed. These outcomes are often multidimensional and each of the dimensions is represented by several indicators with both positive and negative effects on the development outcome. In this study the objective is not only to evaluate the effects of certain policy programs, but also to quantify the state of the outcome. The multidimensionality of the outcome requires the creation of composite indices to have a single measure of performance and also to aggregate the indicators to rank the units in one unique way.

Examples of such indices are studies of globalization and its impacts on inequality, poverty and economic growth. Concerning the measurement of globalization, Heshmati (2006a and 2006b) introduces two composite indices of globalization. The first index is based on the Kearney/Foreign Policy magazine (2002) and the second is obtained from a principal component analysis. They indicate the level of globalization and show how it has developed over time for different countries. The indices are composed of four main components: economic integration, personal contact, technology and political engagement, each generated from a number of indicators. The indices were also used in a regression analysis framework to study the causal relationships between income inequality, poverty, economic growth and globalization. The results show evidence of a weak and negative relationship between globalization and income inequality and poverty. An important index of globalization based on similar methodology, but comprehensive data is the KOF index ${ }^{11}$ (see also Dreher, 2006; and Dreher, Gaston and Martens, 2008).

There are at least two parametric indices employed for computing an index of a development process: the principal component (PC) or factor analysis (FA). In this paper, we introduce a Value Development Index, based on WVS data. Since the two methods in normalized form give PC scores with unit variance, the PC is more frequently used in the analysis of a development process. $^{12}$ PC analysis is a multivariate technique used for examining

\footnotetext{
${ }^{11}$ The 2013 version of the index and underlying data are available at http://globalization.kof.ethz.ch/

${ }^{12}$ Principal Component analysis was originally developed by Pearson (1901) and further improved by Hotelling (1933). The method has been employed in many areas including in computation of a globalization index (Heshmati, 2006a; Andersen and Herbertsson, 2003), an environmental index (Kang, 2002) and a simple globalization index using trade and financial openness by Agénor (2003). Heshmati and Oh (2007) used the
} 
relationships within a set of interrelated quantitative variables. The principal components computed; each is a linear combination of the original indicators with coefficients equal to the Eigen vectors of the correlation of the covariance matrix. The principal components are sorted according to the descending order of the Eigenvalues, which are equal to the variance of the components. PC analysis is a way to uncover approximate linear dependencies among the indicators. Unlike in a traditional least squares estimation method case, where the vertical distance between the observed and the fitted line is minimized, here the sum of the squared residuals is measured as distances from the point to the first principal axis.

As part of the analysis, the Eigenvalues and Eigenvectors are investigated. Only Eigenvalues bigger than 1.0 are used in the computation of development process indices. The Eigenvalues are declining from the first component to other components. By looking at the Eigenvectors, it becomes evident which indicators form a specific component and the nature of their effects. In each sub-component, an indicator with an Eigenvector exceeding 0.30 is considered statistically as a significant contributor to the principal component.

Each of the indices has its own advantages and disadvantages. They can be used to measure the state of development among countries and attribute it to the possible underlying causes. A breakdown of the index into major components provides possibilities to identify positive and negative factors contributing to the development. The structure of the components is determined by the researcher. In practice the researchers use only the first principal component in the computation of a parametric index and in the ranking the countries studied. This method has the disadvantage in that it ignores the information embodied in the remaining indicators. One alternative to account for the information embodied in all principal components with an Eigenvalue bigger than one is to use a weighted average PC index. In the aggregation of the principal components, one can use their explained share of the total variance as weights. This method of aggregation will allow the utilization of information from all indicators of an outcome. Lim and Nguyen (2014) discuss alternative weighting approaches to computing indices of economic activity.

It should be emphasized that the PC method is generally a very useful method to reduce the complexity of the data with multi-dimensions. However, the linear combinations of the different dimensions of interest may not be always easy to interpret. In sum, what is statistically reasonable may be neither economically nor normatively reasonable in the evaluation of development. The non-parametric and parametric indices are computed at each point of the data. In the context of globalization, they show how globalization has developed for different countries and regions over time. A breakdown of the index into major components provides possibilities to identify sources of globalization. The indices can be used to study the causal relationship between globalization, inequality, poverty, growth and a number of other variables.

The factor analysis examined above and various methods of factor rotation have been conducted in the context of linear factor analysis of continuous variables. The standard linear factor-analytic methodologies do not work well for dichotomous items or variables responses. This limitation has led to the development of nonlinear methods. In both cases, the determination of the association between items and factors is the same and is made using factor loading which is considered by Tabachnick and Fidell (2001) as the correlation between the factor and items. Strongest loadings above a threshold value 0.3 or 0.4 are preferred. Nonlinear factor analysis is often used to identify both the presence and nature of multidimensionality in a set of test items. The loaded matrix is rotated in order to amplify the

method for computation of Lisbon Development Strategy Index while Heshmati et al. (2008) used it to study child well-being in the high and middle income countries. 
presence of simple unidirectional latent structures. This is a simple structure from a set of items as when each factor has a few items with high loadings and the rest has loadings near zero.

Finch (2006) conducted a simulation study to compare the performance of two commonly used methods of rotation, namely orthogonal (Varimax) and oblique (Promax) to identify the presence of a simple structure. Factor rotation involves a transformation of the initial factor loadings to obtain a greater simple structure without changing the underlying mathematical relationships in the data. Finch suggests the nonlinear factor analysis rotation method as the preferred method. Orthogonal rotations assume the factors are uncorrelated, while the oblique rotations assume the factors are correlated. The former contains the correlation between the factors, while the later measures the relationship between the individual factors and items. Promax takes the rotated matrix provided by Varimax and raises the loadings to powers where the transformed loading values reflect the simple structure better than in the case of Varimax (McLeod et al., 2001). The results from the Flinch (2001) simulation study suggest that the two approaches are equally able to recover the underlying factor structure, though the promax method is better in the identification of the simple structure. Given conflicting recommendations in the literature, Dien et al. (2005) present a standard protocol for applying PC analysis to event-related potential datasets. The focus is on optimizing PC analysis with emphasis on matrix type, factor loading weighing, extraction and rotations using data simulations.

\section{Re-analysis of Inglehart's data}

Convincing, as Inglehart's theory and the empirics of his contentions might appear at first sight, several essays and books questioned Inglehart's way of combining the analyzed variables into his dimensions or the linkage between his dimensions and democratic development (Hadenius, and Teorell, 2005; Haller, 2002; Haller and Hadler, 2006; Steenkamp and Geyskens, 2012; Tausch and Kharoui, 2011; Tausch and Moaddel, 2009). As we said, principle component analysis or factor analysis with orthogonal standard rotation of factors is a convenient, but not always the best way to reduce the relationships in a statistical correlation matrix between variables. It is of paramount importance to be of the "small print" here - what relationships exist between the factors, and which relationships are being allowed or we might even say are being dictated by the model? No correlations between the factors? Or are correlations being allowed? The statistical method chosen by Inglehart to reduce the complexity of the different components, derived by the initial principal components analysis to arrive at his final factor analytical results - the standard varimax rotation, which allows for no correlations between the chosen factors - today is increasingly being substituted in the literature by better and more advanced methods, like the promax rotation in factor analysis, which exactly allows such correlations between the factors (Finch, 2006). To make matters worse, Inglehart's choice of the WVS data did not always use the items, which are the best available in a maximum number of countries and theoretically of importance at the same time. His analyses are based on a theoretical maximum of 146,789 global interviews reflecting 22 variables; while we thought it more appropriate to base our analysis on a theoretical maximum of 180,041 global interviews for 30 variables.

In our research design, we worked with listwise deletion of missing values. At the end of the day, there were 92,289 persons around the globe with complete data for all the 30 variables of our research design. We worked with the very best documented WVS items. Seen in such a way, the present analysis is the biggest of its kind in social science history ever undertaken. Our "new" nine factors all make very much 'sense' and are free from problematic assumptions. We included all 30 original indicators, into the original principal components 
and later the promax factor analysis. Our research design was thus intended to be more straightforward and simple, and in addition, it uses a more advanced and up to date statistical methodology. In contrast to Inglehart, we also include background variables, like gender, age and education. Thus, our analysis is not anymore a "gender-free zone":

\section{Insert Table 1: The research designs compared}

Our re-analysis is based on 68 countries, and there is a good number of Muslim societies or predominantly Muslim societies with complete data covering all the 30 variables from around the globe. No substitution of missing values had to be carried out, and the SPSS 20 statistics program was applied, with the default options for factor analysis/promax rotation in place. Thus it is important to emphasize that any researcher around the globe could arrive at the same results as we did, independent of culture, religion or moral convictions.

Insert Table 2: The choice of our variables from the World Values Survey

The WVS data we used correspond to $88.96 \%$ of the total global population and $84.75 \%$ of the world's Muslim population; and our re-analysis of the Inglehart world map of human values still yields results with complete data, which are a good sample of $56.89 \%$ of the global population and $56.16 \%$ of the global Muslim population. ${ }^{13}$

\section{The final factor analytical model}

Graph 2 shows the Eigenvalues of our investigation; with the first two factors way past any linear continuation of the factors 10-29, shown in the x-axis. Eight of our nine factors [economic permissiveness, traditional religion, racism, generational education gaps, distrust of the army and the press, authoritarian character, tolerance and respect, and the 'ego' company (independence + selfishness) are not only well above Eigenvalue 1.0, but also way above the linear continuation of the Eigenvalues of factors 9-19. Following such a simple standard procedure of analyzing the Eigenvalues, we suggest to treat the results for factor 9 rejection of the market economy and democracy - with some caution at least. For that reason, our Table 3 lists these results with indented letters.

Although its Eigenvalue is still above 1.0, its vicinity to the factors 10-19 is clearly visible. In all, our model explains some $47 \%$ of the total variance of the correlation matrix of the data for 30 variables from more than 90,000 interview partners of the $W V S$, with two factors explaining already more than $17 \%$ of the total variance in between them - economic permissiveness, and traditional religion, the two defining processes of global values and global value change today. We have highlighted all factor loadings from the rotated structure matrix (Promax rotation according to the SPSS 20 with Kaiser normalization) in different typing and shadings in order to facilitate our readers to arrive at their own independent opinions about our results.

We should emphasize the point that the correlations between the factors are not correlations between aggregations at the country level but reflect the correlations between the factors, to be extracted from the data at the individual level of more than 90,000 interview partners, across countries and across cultures. Under such conditions, correlations between factors of more than $+/-0.10$ are already to be considered high. Nevertheless we have to emphasize that the relationships between economic permissiveness, and traditional religion, the factors with Eigenvalues of 2.0 or above, and the rest of the nine factors under consideration here, all with an Eigenvalue of 1.0 or above, in no way sufficiently firmly confirm the expectations of militant contemporary secularism.

\footnotetext{
${ }^{13}$ WVS five wave aggregated file 1981-2005 (new) available at http://www wvsevsdb com/wvs/WVSData. jsp
} 
Seven factors under consideration here are a new input for the entire global debate about human values. These include: the strength of economic permissiveness, the clear proof of the existence of a factor describing racism, the generation gap in education, connected with the value transformation processes, the existence of a joint political distrust factor against both the army and the press, which also exists in very rich Western democracies, the clear proof of an "authoritarian personality" factor, and a re-emergence of the Hofstede dimension of "long term orientation", called here "the ego company". Two factors bear great semblance to the results, achieved by Inglehart and his associates - traditional religion and tolerance + respect and post-materialism. Our readers are also invited to look at Table 4 for the correlations between the factors and Table 5 for the aggregate country results.

Insert Graph 2: Screeplot for our factor analysis

The following Tables are now to be considered as the main basis of our further interpretations, and form the nucleus of the new choropleth world maps of human values.

Insert Table 3: Structure matrix - Promax with Kaiser normalization

Insert Table 4: The correlations between the factors

Insert Table 5: The country means for the different new factors - mapping the new map of global values on earth

\section{The new choropleth maps of global human values}

Graph 1 depicted the Inglehart/Welzel map of human values. The real choropleth maps, Maps 3 to 11, designed by us on the basis of the preceding WVS data, now focus on our analysis and its geographical implications. We invite our readers first to assess the condensed variable definitions, immediately following from Table 3, and also to assess our list of the five highest and lowest placed countries for each of our nine factors. Readers are then invited to study each of the nine choropleth maps, from Map 3 through to Map 11.

\section{Factor 1. Economic permissiveness definition based on:}

Justifiable: cheating on taxes

Justifiable: avoiding a fare on public transport

Justifiable: someone accepting a bribe

Justifiable: claiming government benefits

Best practice of avoiding it:

Worst practice of avoiding it:

Bangladesh

Serbia

Zimbabwe

Zambia

Turkey

Philippines

Tanzania

Moldova

Morocco

Thailand

\section{Factor 2. Traditional religion definition based on:}

How important is God in your life

Important child qualities: religious faith

Negative loading: never attend religious services

Highest values:

Lowest values:

Nigeria

Ghana

Russian Federation

Jordan

Sweden

Indonesia

Czech Republic

Tanzania

Estonia

Germany 


\section{Factor 3. Racism definition based on:}

[Rejecting] Neighbors: Immigrants/foreign workers

[Rejecting] Neighbors: People of a different race

Immigrant policy (prevent people from coming)

Best practice of avoiding it:

Sweden

Burkina Faso

Canada

New Zealand

Belarus
Worst practice of avoiding it:

Hong Kong

Bangladesh

Jordan

Thailand

India

Factor 4. Generational education gap definition based on:

Highest educational level attained

Rejecting sexist position: University is more important for a boy than for a girl

Negative loading Age

Negative loading Important child qualities: thrift saving money and things

Highest values:

Lowest values:

Dominican Republic

Thailand

Uganda

Mali

Kyrgyzstan

Poland

Nigeria

Czech Republic

Peru

Slovakia

Factor 5. Distrust of the army and the press definition based on:

[No] Confidence: The Press

[No] Confidence: Armed Forces

Negative loading: [Right wing] self-positioning in political scale (scale 1-left to 10-right)

Best practice of avoiding it:

Worst practice of avoiding it:

Viet Nam

Tanzania

Germany

Bangladesh

Argentina

Jordan

Macedonia

India

Trinidad and Tobago

Serbia

Factor 6. The authoritarian character definition based on:

Lack of social capital (Most people can be trusted [highest numerical value: you just can’t be too careful])

Important child qualities: hard work

Important child qualities: obedience

Negative loading: Important child qualities: imagination

Negative loading: Important child qualities: independence

Best practice of avoiding it:

Norway

Sweden

Switzerland

New Zealand

Finland
Worst practice of avoiding it:

Russian Federation

Zimbabwe

Nigeria

Uganda

Trinidad and Tobago 


\section{Factor 7. Tolerance, respect and post-materialism definition based on:}

Important child qualities: tolerance and respect for other people

Important child qualities: feeling of responsibility

Rejecting sexist position: University is more important for a boy than for a girl

Negative loading: Important child qualities: hard work

Best practice:

Sweden

Norway

Switzerland

Finland

Germany
Worst practice:

Mali

Burkina Faso

Ethiopia

Nigeria

Bangladesh

Factor 8. The "ego company" definition based on:

Important child qualities: feeling of responsibility

Important child qualities: independence

Negative loading: Important child qualities: unselfishness

Negative loading: Important child qualities: obedience

Highest values:

Lowest values:

South Korea

Burkina Faso

Azerbaijan

Zimbabwe

Taiwan

Jordan

Latvia

Ghana

Estonia

Tanzania

Factor 9. The rejection of the market economy and democracy defined based on:

Sex (Gender) [in multivariate analysis: female] (1=male; $2=$ female)

Competition good or harmful

Political system: (It's very bad] having a democratic political system

Best practice of avoiding it:

Worst practice of avoiding it:

Nigeria

Poland

Bangladesh

Chile

Morocco

Guatemala

India

Uruguay

Jordan

Thailand

\section{Regional value differences at the sub-national level}

The World Value Survey data also permit the research community to analyze the results not only at the national level, but also at the regional level, where the interviews were recorded.

The idea that global values are often present in the nations of the world in a highly regionally contradictory pattern, is relatively new in the research literature on the subject, but has tremendous political and also international implications. First studies in this direction were published, among others, by Torgier and Schneider (2007). Of the global regions with more than 30 interview partners each, it emerges for example that the 30 most economically permissive social climates are located in: 


\begin{tabular}{|l|l|}
\hline Copperbelt Province & Zambia \\
\hline South East Serbia & $\begin{array}{l}\text { Serbia \& } \\
\text { Montenegro }\end{array}$ \\
\hline Central West Serbia & $\begin{array}{l}\text { Serbia and } \\
\text { Montenegro }\end{array}$ \\
\hline Vulkaneshtskij & Moldova \\
\hline $\begin{array}{l}\text { Autonom Gaugasian } \\
\text { Rep. }\end{array}$ & Moldova \\
\hline Zhitomyr oblast & Ukraine \\
\hline Arges & Romania \\
\hline Sahel Region & Burkina Faso \\
\hline Kirovograd oblast & Ukraine \\
\hline Northern & Ghana \\
\hline
\end{tabular}

\begin{tabular}{|l|l|}
\hline Assam & India \\
\hline Mopti & Mali \\
\hline Ararat Marz & Armenia \\
\hline Southern & Ukraine \\
\hline Central & Ukraine \\
\hline Gomel oblast & Belarus \\
\hline Sikasso & Mali \\
\hline Ziemelu reg. & Latvia \\
\hline Kampala & Uganda \\
\hline Altiplano/Centro & Guatemala \\
\hline
\end{tabular}

The 30 superstars of economic law-abiding (=highest negative loadings on the economic permissiveness factor) we find in the following regions of the world:

\begin{tabular}{|l|l|}
\hline Kishoreganj & Bangladesh \\
\hline East Central Anatolia & Turkey \\
\hline Feni & Bangladesh \\
\hline Mymensingh & Bangladesh \\
\hline Western Black Sea & Turkey \\
\hline Sylhet & Bangladesh \\
\hline Western Marmara & Turkey \\
\hline Chittagong & Bangladesh \\
\hline Rangpur & Bangladesh \\
\hline Habiganj & Bangladesh \\
\hline Samegrelo & Georgia \\
\hline Masvingo & Zimbabwe \\
\hline Brahmanbaria & Bangladesh \\
\hline Lampung & Indonesia \\
\hline Mashonaland West & Zimbabwe \\
\hline Addis Ababa & Ethiopia \\
\hline
\end{tabular}

\begin{tabular}{|l|l|}
\hline East Java & Indonesia \\
\hline Eastern Black Sea & Turkey \\
\hline Midlands & Zimbabwe \\
\hline Nator & Bangladesh \\
\hline Northwest & Vietnam \\
\hline Sirajgonj & Bangladesh \\
\hline Marrakech-Tensift & Morocco \\
\hline Punjab & India \\
\hline Eastern Marmara & Turkey \\
\hline $\begin{array}{l}\text { Dareah Istimewa } \\
\text { Yogyakarta }\end{array}$ & Indonesia \\
\hline North central & Vietnam \\
\hline Western Anatolia & Turkey \\
\hline Dhaka & Bangladesh \\
\hline Mashonaland Central & Zimbabwe \\
\hline Barisal & Bangladesh \\
\hline
\end{tabular}

The 30 most racist and xenophobic cultures of the world are to be found in the following regions:

\begin{tabular}{|l|l|}
\hline Sirajgonj & Bangladesh \\
\hline Jharkhand & India \\
\hline Brahmanbaria & Bangladesh \\
\hline Kishoreganj & Bangladesh \\
\hline Feni & Bangladesh \\
\hline Nator & Bangladesh \\
\hline Habiganj & Bangladesh \\
\hline Sylhet & Bangladesh \\
\hline Chittagong & Bangladesh \\
\hline Barisal & Bangladesh \\
\hline Banten & Indonesia \\
\hline Dhaka & Bangladesh \\
\hline Eastern & Ghana \\
\hline The South & Thailand \\
\hline Assam & India \\
\hline Mymensingh & Bangladesh \\
\hline Comilla & Bangladesh \\
\hline
\end{tabular}

\begin{tabular}{|l|l|}
\hline Central Anatolia & Turkey \\
\hline Madhya Pradesh & India \\
\hline Rajasthan & India \\
\hline The North & Thailand \\
\hline West Bengal & India \\
\hline Orrisa & India \\
\hline Bihar & India \\
\hline Northwest & Vietnam \\
\hline $\begin{array}{l}\text { Jeonbuk/North } \\
\text { Jeolla }\end{array}$ & Korea-South \\
\hline DKI & Indonesia \\
\hline $\begin{array}{l}\text { Copperbelt } \\
\text { Province }\end{array}$ & Zambia \\
\hline Southeast & Vietnam \\
\hline $\begin{array}{l}\text { Dareah Istimewa } \\
\text { Yogyakarta }\end{array}$ & Indonesia \\
\hline
\end{tabular}


On a European level, one should not underestimate the long-term implications of such findings. It emerges, for example, that even in highly developed overseas democracies, regional value differences are considerable, as, say, between the deeply religious "Bible Belt" in the US South and the relatively secular New England. Secular Western Turkey quickly catches up with other European regions concerning the "Westernization" of values. Table 7 provides us with a first overview of the highest and lowest placed regions in the current EU members and the EU-accession countries, ranked by an average Value Development Index score which is based on the factor analytical results, presented on the country to country level in Table 5 and on the Eigenvalues, presented in Graph 2 of this work. The factor analytical parametric index comprises the following variables: avoiding economic permissiveness; avoiding racism; avoiding distrust of the army and the press; avoiding the authoritarian character; tolerance and respect; and avoiding the rejection of the market economy and democracy. Our Table 7 suggests huge regional differences in the EU, which will increase even more after the next proposed round of EU-enlargement.

The results from Table 8 reveal some very unfortunate results about the still persistent absence of a climate of social tolerance in some Turkey's regions. Of all global regions with available data with 30 or more interview partners per region, the Turkish region of Western Marmara had rank 13 for the presence of an authoritarian character, and the Eastern Black Sea region was rank 41 of the more than 500 classified regions on this scale. Central Anatolia was global rank 18 in the global scale of regional racism, and the Western Black Sea region was rank 31 on this indicator. Central Anatolia was down at the very bottom of global regions with an achieved rank 457 in the scale of tolerance and respect and post-materialism, while the rankings for the Aegean region and partly also Istanbul were much more favorable.

Insert Table 7: The rankings of the best and the worst ranked regions in the EU and the candidate and potential candidate countries

Insert Table 8: The rank of Turkish regions in the geography of global values

\section{Turkey - a Torn Country? Conclusions and Perspectives}

In the following, we will use factor analytical scores to calculate a new Global Value Development Index, which uses the measurement scales (factors) of our work, and which hopefully will be recognized by religious and non-religious readers alike as measurement scales. Thes cales express the true degree of development of a civil society of a country, independent from the extent of traditional religion in the country, and also independent from the educational gap, and also independent from the factor "ego company", where different cultural codes of global society might sharply diverge on the assessment on whether this is a "good" or "bad phenomenon".

Thus, our Global Value Development Index country score combines: avoiding permissiveness, pessimism; avoiding racism; avoiding distrust of the army and the press; avoiding the authoritarian character; tolerance and respect + post-materialism; and avoiding the rejection of the market economy and democracy. The weight, given to each factor, corresponds to the Eigenvalues listed in Graph 2 of this work.

We have to emphasize at the outset that the six dimensions combine phenomena, where Turkey is among the top $30 \%$ of global society, i.e. avoiding economic permissiveness and avoiding the distrust of the army and the press as the long-lasting influences of Kemalism on Turkish society at large. The combined indicator also includes two components, where Turkey's performance is rather mediocre, compared to other countries (tolerance and respect and avoiding the rejection of the market economy and democracy), while the results for 
avoiding racism and for avoiding the authoritarian character are among the bottom $20 \%$ of global society. Due to the positive performance concerning economic morality and also the trust in the empirically most important two pillars of a free and democratic society - the army and the press - and the weight that these factors have in the overall model of global values, the overall Turkish performance, emerging from Table 9, is quite positive. However, we have to emphasize that this performance corresponds - as the chapter heading suggests - to the experience of a culturally much divided country.

Our country results show that the five best ranked countries of our entire globe are all western democracies with a solid historical anchoring of their societies in the traditions of liberal Enlightenment, Switzerland, Norway, Sweden, New Zealand, and Australia. But we already find among the next five countries the two developing countries Vietnam and Tanzania, and the EU-member countries Italy (predominantly Roman Catholic), Finland (predominantly Protestant) and Canada. Our global value development index, combining law-abiding and social capital, avoiding racism; trust of the army and the press; no authoritarian character; a high degree of tolerance and respect; and a high acceptance of the market economy and democracy, ranks the predominantly Muslim nation of Morocco twelfth - just behind the United States of America - and still ahead the Latin American democracy Uruguay and Germany, to be followed by Bosnia and Indonesia.

Insert Table 9: The rankings of the countries of the world based on a new Global Value Development Index

While in general terms, our analysis is quite optimistic about the civil society foundations for a stable democracy for several Muslim countries, including Morocco, Bosnia, Indonesia, Turkey and Jordan, our analysis is fairly pessimistic for the former communist countries and successor states of the former Soviet Union, predominantly Muslim and non-Muslim alike. They excel hardly anywhere by an overwhelmingly positive performance, while the history of communism, which began to be implemented in Russia in 1917, destroyed the religious fabric of society and left a hyper-authoritarian society in place. Russia's percentile performance scores, which might be interpreted as a serious question mark about Russia's future trajectory, are the following: the 'ego' company (18\%), avoiding the distrust of the army and the press (61\%), avoiding economic permissiveness (78\%), tolerance and respect (79\%), avoiding the rejection of the market economy and democracy (87\%), traditional religion (100\%) and avoiding the authoritarian character (100\%).

Our map, built on the results of Table 9, also shows that some of the assumptions by European decision makers, which pushed EU enlargement ahead of democratic consolidation after the fall of Communism in Eastern Europe, are wrong. The degree of development of a democratic civil society, characterized by law-abiding and social capital, avoiding racism; trust of the army and the press; no authoritarian character; a high degree of tolerance and respect; and a female acceptance of the market economy and democracy is very poorly developed in several of the countries, admitted into the EU in 2004 and after. Our choropleth map of global value development (Map 12) then summarizes the results of Table 9 at a glance.

\section{Insert Map 12: Combined global value development index}

It is also interesting to note how neighboring countries, diverge in their value patterns: just compare Uruguay and Brazil, both predominantly Roman Catholic; Italy and Hungary, both predominantly Roman Catholic, Morocco and Mali, both predominantly Muslim, or for that matter, Morocco and Spain, just separated by the Straits of Gibraltar; Tanzania and Zambia, two neighboring African countries, and Vietnam and Thailand, two Asian neighboring countries. While Uruguay, Italy, Morocco, Tanzania and Vietnam are real frontrunners in overall value development, we find that Brazil; Hungary, Mali, Zambia, and Thailand are real 
laggards in global value development. These phenomena hold independently of the attained development level of a country, measured by the Human Development Index of the UNDP. All of a sudden we discover, how exceptional countries like Uruguay, Italy, Morocco, Tanzania and Vietnam really are, and that global social science research would do well to focus on the value structures in these countries.

As we already noted, however, Turkey's overall performance is mainly due to its good ranking in the field of economic morality and also by the trust of its public in pillars of a free and democratic society. Using again the factor analytical method for the indicators: avoiding racism, absence of an authoritarian character, tolerance and respect, and avoiding the rejection of the market economy and democracy, we however realize that Turkey is only rank 61 of the global scale of 67 classified countries. Since such a ranking immediately follows from Tables 5 and 10, this contention does not need a further proof here. ${ }^{14}$

Of all the nations on earth with available data, there is a very high racism, a very pronounced authoritarian character, little tolerance and respect and postmaterialism, and a relatively high rejection of democracy and the market economy. Table 10 shows the factor analytically weighted results - with the Eigenvalues as the weights for the factors. For Turkey's accession to the EU, these results imply an important agenda for the future: the state of law and secular democracy in Turkey and respect for minority rights must be strengthened. The recent announcement that there will be special prisons for persons with a homosexual sexual orientation must be interpreted as the very last event in a recent long chain of actions on the part of the current, incumbent Turkish administration to de-Westernize the country in the name of a mystical "Ummah" instead of liberal democracy. ${ }^{15}$

Insert Table 10: Turkey's global ranking on tolerance and democracy indicators

Just how important the dimension of tolerance, respect and postmaterialism is for "effective democracy" we realize when we look at the bi-variate scatterplots on liberal values as the drivers of "effective democracy", which we define with Alexander, Inglehart and Welzel, 2012 as the combination of civil rights with the absence of corruption (Graph 3).

Insert Graph 3: Liberal values as a drivers of "effective democracy”

In the long run, we are optimistic about the human development and security. All social scientific evidence seems to suggest that Turkey is indeed on a path of long-lasting changes and quite spectacular societal re-alignments. Among all the available social indicators of the world, infant mortality per 1.000 live births is among the most reliable, direct and completely documented indicator of the presence or absence of mass poverty. The economic basis for future coming changes in Turkey is the positive social development during the last decade and a half, which we can witness at the World Bank's data site with infant mortality now, in 2012, at 12.2, down from the 171.1 in $1960 .{ }^{16}$ We realize at once how deeply AKP rule has transformed the formerly poor Turkish villages and urban Gecekondular (shanty towns). This spectacular social change is also evident from the fact that from 2000 onwards, Turkey increased its global ranking in overcoming infant mortality by another spectacular improvement of 16 ranks, only surpassed by Iran, South Korea, China and Tunisia.

Increased human development, rising life expectancy and reduced infant mortality are all a sign of rising human security. One of the robust lessons of global value research is that with increasing human security, peoples' longings for democracy, tolerance and civil society will increase. Issues of post-materialism will become important, precisely for those young

\footnotetext{
${ }^{14}$ We relegated the results from the combined results for Serbia and Montenegro from the original list, so the number of countries was reduced from 68 to 67.

${ }^{15} \mathrm{http}: / /$ www.reuters.com/article/2014/04/15/us-turkey-prisons-segregation-idUSBREA3E0VC20140415

16 http://data.worldbank.org/indicator/SP.DYN.IMRT.IN
} 
generations, who could afford themselves a decent education at one of the country's thriving Universities, including from Turkey's rapidly rising middle class. Their parents and grandparents were lifted out of poverty during the last decades. But as so often happens in history, a particular social and political movement might have served a country well for a longer period, only to be confronted with the situation that the very policies of a given regime reach its limits, and changed a country for the better, entering a period for which the thought patterns and receipts of the successful past no longer fit the needs of the future. Democracy, post-materialism, urban development, gender issues, and a "soft" and humanistic reading of the great plural religious heritage of the country will become the order of the day, precisely corresponding to the predictions of the theories of value change, which we presented in this essay.

To wind up our comparisons, we have calculated our results with population weighted averages for the Anglo-Saxon overseas democracies (Australia, Canada, New Zealand, United States), which are the real frame of reference of any EU-2020 or European "Lisbon Strategy" comparison; the EU countries with available data (Bulgaria; Cyprus; Czech Republic; Estonia; Finland; Germany; Hungary; Italy; Latvia; Lithuania; Poland; Romania; Slovakia; Slovenia; Spain; Sweden), Turkey and Russia. In terms of a "Lisbon strategy" to make Europe the most advanced economic and social region on earth, performing better than the United States or, for that matter, Australia, Canada, or New Zealand, Turkey's accession to the EU will not provide a critical mass of positive assets of values, like avoiding racism; avoiding the authoritarian character; tolerance and respect; and avoiding the rejection of the market economy and democracy.

Yeşilada and Noordijk (2010) already came to the conclusion that Turkish public has become more conservative (traditional on the Inglehart-Welzel factor of the traditional-secular/ rational scale) during the period of 1995 to 2005. Their findings indicate that this is not a phenomenon that started with election of the AKP in 2002. The authors maintain that it is a trend that can be traced to 1995 and has intensified toward more conservatism since then. Our essay confirms their basic analysis. At the same time, Yeşilada and Noordijk think that a slight but significant shift in survival-self-expression values was observed: a regressive shift from 1990 to 2000 followed by a slight return toward more self-expression in 2005. Since 1994 the Turkish electorate as a bloc, Yeşilada and Noordijk argue, has moved to the right of the political spectrum. The authors suggest that Turkish society is far from values observed in many EU member states with respect to religiosity and Inglehart and Welzel's values map.

Abdollahian, Coan, Oh and Yeşilada (2012) however were correct in pointing out the basic dilemma for the AKP leadership under Erdoğan: Turkey as a high-performer on the Human Development Index dimension will sooner or later face the enormous pressures in the direction of democratization and self-expression values, which any society around the globe faces, when human development is in a rapid and positive direction. The authors say that economic progress has important implications for the evolution of rational-secular and selfexpression value orientations. Specifically, the interactive relationship between progress and value orientations suggests, Abdollahian et al. argue, that major changes in existential conditions moderate the ebb and flow of cultural evolution. The expected rate of change in both rational-secular values and self-expression are related to where a nation is located in the development process. Moreover, Abdollahian et al. (2012) derive predictions about a zone of democratic transition and a zone of revolutionary change. Revolutionary change in political institutions suggests pronounced forces for change when political expectations fail to align with political realities. Nations could become trapped in an oscillating system characterized by unmet demands for political change and instability. Economic progress is a necessary condition for successful secularization and expressive political behavior, which precede lasting democratic institutions. The real test for Erdoğan and the AKP will come when Turkey 
enters the phase of information and knowledge based services and will ever-more face the impact that technology has on culture, politics, and development. In Huntingtons view " $A$ bridge... is an artificial creation connecting two solid entities but is part of neither. When Turkey's leaders term their country a bridge, they euphemistically confirm that it is torn." (Huntington 1996: 149)

Graph 4 and Table 11 support our verdict that the member countries of the EU and the European Commission should carefully weigh the costs and benefits of further enlargements, also in terms of the value balances in comparison to the world's leading democracies and the ascending democracies in Latin America and other regions of the world, which conform much better to the essence of the values of the Enlightenment.

Insert Graph 3: Liberal values as a drivers of "effective democracy”.

Insert Graph 4: Population-weigthed value structures for selected countries and country groups.

\section{Literature}

Abdollahian M. A., Coan T. G., Oh H. and Yeşilada, B. A. 2012. Dynamics of Cultural Change: The Human Development Perspective. International Studies Quarterly, 56, 827842.

Alesina A. 2013. Women, Fertility and the Rise in Modern Capitalism. Science, 342(6157), 427-428.

Alesina A. and Angeletos G. M. 2005. Fairness and Redistribution. American Economic Review, 95(4), 960-980.

Alesina A. and Fuchs-Schündeln N. 2007. Goodbye Lenin (or Not?): The Effect of Communism on People. American Economic Review, 97(4), 1507-1528.

Alesina A. and Giuliano P. 2010. The Power of the Family. Journal of Economic Growth, 15, 93-125.

Alesina A. and Giuliano P. 2011. Family Ties and Political Participation, Journal of the European Economic Association, 9(5), 817-839.

Alesina A. and Guiliano P. 2013. Culture and Institutions. NBER Working Paper Series, Working Paper 19750.

Alesina A., Cozzi, G., and Mantovan N. 2012. The Evolution of Ideology, Fairness, and Redistribution. The Economic Journal, 122 (565), 1244-1261.

Alesina A., Di Tella R., and MacCulloch R. 2004. Inequality and Happiness: Are Europeans and Americans Different? Journal of Public Economics, 88(9-10) 2009-2042.

Alexander A., R. Inglehart R. and Welzel C. 2012. Measuring Effective Democracy: A Defense. International Political Science Review, 33(1), 41-62.

Andersen T. M. and Herbertsson T. T. 2003. Measuring Globalization. IZA Discussion Paper 2003:817.

Barro R. J. and McCleary R. M. 2003. Religion and Economic Growth across Countries. American Sociological Review, 68(5), 760-781.

Biswas A. K., Farzanegan M. R. and M. Thum M. 2012. Pollution shadow economy and corruption-theory and evidence, Ecological Economics, 75, 114-125.

Blackburn K., Bose N. and Capasso S. 2012. Tax evasion, the underground economy and financial development. Journal of Economic Behavior \& Organization, 83(2), 243-253.

Chaudhuri K., Schneider F. and Chatt, opadhyay S. 2006. The size and development of the shadow economy-an empirical investigation from states of India, Journal of Development Economics, 80, 428-443.

Clesse A. and Tashan S. 2004. Turkey and the EU: 2004 and beyond. Amsterdam: Dutch University Press. 
D'Hernoncourt D. and Meon P. G. 2012. The not so dark side of trust: Does trust increase the size of the shadow economy?, Journal of Economic Behavior \& Organization, 81, 97121.

Dien J., Beal D. J. and Berg P. 2005. Optimizing principal components analysis of eventrelated potentials: Matrix type, factor loading weighting, extraction, and rotations, Clinical Neurophysiology, 16, 1808-1825.

Diez-Nicolas J. 2007. Value Systems of Elites and Publics in the Mediterranean: Convergence and Divergence. In 'Values and Perceptions of the Islamic and Middle Eastern Publics' (Moaddel M. (Ed.)): 47-70, Houndmills, Basingstoke, Hampshire: Palgrave Macmillan.

Diez-Nicolas J. 2010. Cultural Differences on Values about Conflict, War, and Peace. World Values Research, 3(1), 1-20.

Dreher A., Gaston N. and Martens P. 2008. Measuring Globalisation: Gauging its Consequences. New York: Springer.

Dreher A. 2006. Does Globalization Affect Growth? Evidence from a new Index of Globalization, Applied Economics, 38(10), 1091-1110.

Eilat Y. and Zinnes C. 2002. The Shadow Economy in Transition Countries: Friend or Foe? A Policy Perspective, World Development, 30(7), 1233-1254.

Elgin C. and Uras B. R. 2012. Public debt, sovereign default risk and shadow economy, Journal of Financial Stability, forthcoming.

Erişen C., Erişen E. and Özkeçeci-Taner B. 2013. Research Methods in Political Psychology. Turkish Studies, 14(1), 13-33.

Finch H. 2006. Comparison of the Performance of Varimax and Promax Rotations: Factor Structure Recovery for Dichotomous Items, Journal of Modern Applied Statistical Methods, 10(2), Article 14.

Hadenius A., and Teorell J. 2005. Cultural and economic prerequisites of democracy: Reassessing recent evidence. Studies in Comparative International Development, 39(4), 87-106

Haller M. 2002. Theory and Method in the Comparative Study of Values: Critique and Alternative to Inglehart. European Sociological Review, 18(2), 139-158.

Haller M. and Hadler M. 2006. How Social Relations and Structures Can Produce Happiness and Unhappiness: An InternationalComparative Analysis. Social Indicators Research, 75(2), 169-216.

Heshmati A., Tausch A. and Bajalan C. 2008. Measurement and Analysis of Child WellBeing in Middle and High Income Countries. European Journal of Comparative Economics, 5(2), 227-286.

Heshmati A. 2006a. Measurement of a Multidimensional Index of Globalization, Global Economy Journal, 6(2), Article 1.

Heshmati A. 2006b. The Relationship between Income Inequality Poverty, and Globalization, in The Impact of Globalization on the World's Poor (M. Nissanke and E. Thorbecke, (Eds.)), Basinsgtoke and New York: Palgrave Macmillan, pp. 59-93.

Heshmati A. 2007. Global Trends in Income Inequality. Hauppauge, N.Y.: Nova Science Publishers.

Heshmati A. and Lee S. 2010. The Relationship between Globalization, Economic Growth and Income Inequality. Journal of Globalization Studies, 1(2), 87-117.

Heshmati A. and Oh J-E. 2006. Alternative Composite Lisbon Development Strategy Indices: A Comparison of EU, USA, Japan and Korea. The European Journal of Comparative Economics, 3(2), 133-170.

Heshmati A. and Tausch A. 2007. Eds. Roadmap to Bangalore? Globalization, the EUs Lisbon Process and the Structures of Global Inequality. Hauppauge, N.Y.: Nova Science Publishers. 
Hofstede G., Hofstede G. J. and Minkov, M. 2010. 'Cultures and Organizations: Software of the Mind.' Revised and expanded 3rd Edition. New York: McGraw-Hill.

Hofstede G. 2001. Culture's consequences: comparing values, behaviors, institutions, and organizations across nations. Thousand Oaks, Calif.: Sage Publications.

Hofstede G. and Minkov M. 2010. Long- versus short-term orientation: new perspectives. Asia Pacific Business Review, 16(4), 493-504.

Huntington S. P. 1993. The Clash of Civilizations? Foreign Affairs, 72(3), 22-49.

Huntington S. P. 1996. The clash of civilizations and the remaking of world order. New York: Simon \& Schuster.

IBM. 2011. IBM SPSS Statistics 20 Algorithms. Armonk, New York.

Indjikian R. and Siegel D. S. 2005. The impact of investment in IT on economic performance: implications for developing countries, World Development, 33(5), 681-700.

Inglehart R. F. 2003. Islam, Gender, Culture, and Democracy. (Ronald Inglehart Ed). Willowdale, ON, Canada: de Sitter.

Inglehart R. F. and Baker, W. E. 2000. Modernization, Cultural Change, and the Persistence of Traditional Values. American Sociological Review, 65(1), 19-51.

Inglehart R. F. and Norris P. 2003. Rising tide: gender equality and cultural change around the world. Cambridge, UK; New York: Cambridge University Press, 2003.

Inglehart R. F. and Welzel C. 2003. Political Culture and Democracy: Analyzing Cross-Level Linkages. Comparative Politics, 36(1), 61-79.

Inglehart R. F. and Welzel C. 2005. Modernization, Cultural Change and Democracy. New York: Cambridge University Press, 2005.

Kang S. M. 2002. A Sensitivity Analysis of the Korean Composite Environmental Index. Ecological Economics, 43, 159-174.

Kearney A. T., Inc., The Carnegie Endowment for International Peace. 2002. Globalization's Last Hurrah?. Foreign Policy. January/February, 38-51.

Lim G.C. and V.H. Nguyen (2014), Alternative weighting approaches to computing indices of economic activity, Journal of Economic Surveys, in press.

McLeod L. D., Swygert K. A. and Thissen D. 2001. Factor analysis for items scored in two categories. In: Test scoring (D. Thissen \& H. Wainer (Eds.)), pp. 189-216). Mahwah, N. J.: Erlbaum.

Minkov M. 2009. Predictors of Differences in Subjective Well-Being across 97 Nations. Cross-Cultural Research, 43, 152-179.

Minkov M. and Hofstede G. 2011. Cultural differences in a globalizing world. Bingley, UK: Emerald.

Minkov M. and Hofstede G. 2013. Cross-cultural analysis: the science and art of comparing the world's modern societies and their cultures. Los Angeles: Sage.

Moaddel M. 2002. The Study of Islamic Culture and Politics: An Overview and Assessment. Annual Review of Sociology, 28, 359-86.

Moaddel M. 2003. Public Opinion in Islamic Countries: Survey Results. Footnotes, 31(1).

Moaddel M. 2008. Religious Regimes and Prospects for Liberal Politics: Futures of Iran, Iraq, and Saudi-Arabia. World Values Research, 1(2), 36-58.

Morel J. SJ. 2003. Radikale Kirchenreform: für eine mutige Erneuerung: Fakten und religionssoziologische Theorien über die Krise der katholischen Kirche von 1950 bis in die Gegenwart als Entscheidungsgrundlagen notwendiger Reformen. Innsbruck: TyroliaVerlag.

Negrón-Gonzales M. 2012. Cooperation between Secular and Religious Rights Organizations in Turkey. Turkish Studies, 13(3), 415-430.

Sarigil Z. 2011. Civil-Military Relations Beyond Dichotomy: With Special Reference to Turkey. Turkish Studies, 12(2), 265-278. 
Schneider F. 2005. Shadow economies around the world: what do we really know? European Journal of Political Economy, 21, 598-642.

Şimşek S. 2013. Conservative Democracy as a Cosmetic Image in Turkish Politics: The Semiology of AKP's Political Identity. Turkish Studies, 14(3), 429-446.

SPSS, 2007. Statistical Package for the Social Sciences, User Guide. Version 14, August 2007.

Steenkamp J. -B. E. M. and Geyskens I. 2012. Transaction cost economics and the roles of national culture: A test of hypotheses based on Inglehart and Hofstede. Journal of the Academy of Marketing Science, 40(2), 252-270.

Tabachnick B. G. and Fidell L. S. 2001. Using multivariate statistics. Needham Heights, MA: Allyn \& Bacon.

Tanzi V. 1999. Uses and abuses of estimates of the underground economy. Economic Journal, 109, 338-340.

Tanzi V. and Schunecht L. 1997. Reconsidering the fiscal role of government: the international perspective. American Economic Review, 87, 164-168.

Tausch A. and Karoui H. 2011. Les Musulmans: Un cauchemar ou une force pour l'Europe? Paris: Harmattan.

Tausch A. and Moaddel M. 2009. What 1. 3 billion Muslims really think. An answer to a recent Gallup study, based on the 'World Values Survey'. Hauppauge, N.Y.: Nova Science Publishers.

Tessler M. 2003. Arab and Muslim Political Attitudes: Stereotypes and Evidence from Survey Research. International Studies Perspectives, 4, 175-80.

Toghill J. 2012. Are the official economic and political obstacles to Turkey's EU accession merely a 'fig leaf' covering real unofficial cultural and religious reservations? POLIS Journal, 6, Winter 2011/2012.

Torgier B., and Schneider, F. 2007. What shapes attitudes toward paying taxes? Evidence from multicultural European countries. Social Science Quarterly, 88(2), 443-470.

Torgler B., and García-Valiñas M. A. 2007. The determinants of individuals' attitudes towards preventing environmental damage. Ecological Economics, 63(2-3), 536-552.

Torgler B. and Schneider F. 2009. The impact of tax morale and institutional quality on the shadow economy. Journal of Economic Psychology, 30, 228-245.

UNDP 2013. Human Development Report 2013. The rise of the South: Human progress in a diverse world, United Nations Development Program.

Yeşilada B. A. 2002. The Virtue Party. Turkish Studies, 3(1), 62-81.

Yeşilada B. A. and Noordijk P. 2010. Changing Values in Turkey: Religiosity and Tolerance in Comparative Perspective. Turkish Studies, 11(1), 9-27. 
Arno Tausch is an Austrian citizen and in his academic functions he is Adjunct Professor of Political Science at Innsbruck University, Department of Political Science. Currently, he is also Associate Professor of Economics, Corvinus University, Budapest, and Lecturer of International Development, Vienna University. He served as an Austrian diplomat abroad and was Counselor for Labor and Migration at the Austrian Embassy in Warsaw. His research program is focused on world systems studies, development and dependency studies, European studies, and quantitative world values and peace research. He authored or co-authored books and articles for major international publishers and journals, among them 16 books in English, 2 in French, 8 books in German, and over 220 printed or electronic scholarly and current affairs publications. His publications include a number of essays for leading economic and foreign policy think tanks, and for the Jean Monnet Institutes of the EU.

Almas Heshmati, a Swedish citizen, is currently Professor of Economics at Jönköping University and Sogang University. He held similar positions at the Korea University, Seoul National University, and University of Kurdistan Hawler. He was Research Fellow at the World Institute for Development Economics Research (WIDER), during 2001-2004. From 1998 until 2001, he was an Associate Professor at the Stockholm School of Economics. He has a Ph.D. degree from the University of Gothenburg 1994. His research interests include applied microeconomics, globalization, development strategy, efficiency, productivity and growth with application to manufacturing and services. In addition to more than 120 scientific journal articles he has published books on EU Lisbon Process, Global Inequality, East Asian Manufacturing, Chinese Economy, Technology Transfer, Information Technology, Water Resources, Landmines, Power Generation, Development Economics and Economic Growth. 
Table 1: The research designs compared

\begin{tabular}{|c|c|c|}
\hline & Inglehart and associates & Our re-analysis \\
\hline Choice and naming of the dimensions & $\begin{array}{l}\text { ex ante, perhaps controversial, } \\
\text { for example that survival values } \\
\text { (and not tradition values) } \\
\text { include the divorce and } \\
\text { abortion item and the limits on } \\
\text { selling foreign goods item, } \\
\text { while the item on incomes and } \\
\text { jobs, currently listed in the } \\
\text { traditional values dimensions, } \\
\text { very plausibly might be listed } \\
\text { under the survival dimension }\end{array}$ & $\begin{array}{l}\text { ex post, as suggested by } \\
\text { the empirical results; the } \\
\text { results were compared to } \\
\text { the literature }\end{array}$ \\
\hline Factor analytical design & $\begin{array}{l}\text { standard factor analysis using } \\
\text { orthogonal varimax rotation } \\
\text { (does not allow for correlations } \\
\text { between the factors) }\end{array}$ & $\begin{array}{l}\text { more advanced versions of } \\
\text { factor analysis, allowing } \\
\text { for relationships between } \\
\text { the factors (Promax } \\
\text { rotation) }\end{array}$ \\
\hline $\begin{array}{l}\text { Inclusion of socio-economic background } \\
\text { variables like age, education in the model }\end{array}$ & no & yes \\
\hline $\begin{array}{l}\text { Number of countries, considered in the } \\
\text { analysis }\end{array}$ & 65 & 68 \\
\hline $\begin{array}{l}\text { Number of variables in the original } \\
\text { analysis }\end{array}$ & 22 variables/later reduced to 10 & 30 \\
\hline $\begin{array}{l}\text { Results are based on items, available for } \\
\text { at least the following number of } \\
\text { respondents }\end{array}$ & 146,789 & 180,041 \\
\hline $\begin{array}{l}\% \text { of total variance explained at the } \\
\text { individual analysis level }\end{array}$ & $\begin{array}{c}26 \% \text { (traditional values) }+13 \% \\
\text { (survival values) }\end{array}$ & $47.89 \%$ \\
\hline
\end{tabular}


Table 2: The choice of our variables from the World Values Survey

\begin{tabular}{|c|c|c|}
\hline Variable label & $\begin{array}{l}\text { Interpretation of the variable according to the } \\
\text { highest numerical value }\end{array}$ & $\begin{array}{c}\text { Observatio } \\
\text { ns }\end{array}$ \\
\hline Age & Age & 247,978 \\
\hline Competition good or harmful & Competition good or harmful & 203,976 \\
\hline Confidence: Armed Forces & [No] Confidence: Armed Forces & 231,665 \\
\hline Confidence: The Press & [No] Confidence: The Press & 236,529 \\
\hline Highest educational level attained & Highest educational level attained & 230,283 \\
\hline How important is God in your life & How important is God in your life & 240,112 \\
\hline $\begin{array}{l}\text { How often do you attend religious } \\
\text { services }\end{array}$ & $\begin{array}{l}\text { [Never attend religious services. Scale: ] } \\
\text { How often do you attend religious services }\end{array}$ & 238,981 \\
\hline $\begin{array}{l}\text { Immigrant policy (prevent people from } \\
\text { coming) }\end{array}$ & $\begin{array}{l}\text { Immigrant policy (prevent people from } \\
\text { coming) }\end{array}$ & 187,066 \\
\hline $\begin{array}{l}\text { Important child qualities: determination } \\
\text { and perseverance }\end{array}$ & $\begin{array}{l}\text { Important child qualities: determination and } \\
\text { perseverance }\end{array}$ & 247,782 \\
\hline $\begin{array}{l}\text { Important child qualities: feeling of } \\
\text { responsibility }\end{array}$ & $\begin{array}{l}\text { Important child qualities: feeling of } \\
\text { responsibility }\end{array}$ & 255,656 \\
\hline Important child qualities: hard work & Important child qualities: hard work & 253,331 \\
\hline Important child qualities: imagination & Important child qualities: imagination & 252,238 \\
\hline Important child qualities: independence & Important child qualities: independence & 255,656 \\
\hline Important child qualities: obedience & Important child qualities: obedience & 255,656 \\
\hline Important child qualities: religious faith & Important child qualities: religious faith & 253,503 \\
\hline $\begin{array}{l}\text { Important child qualities: thrift , and } \\
\text { saving money and things }\end{array}$ & $\begin{array}{l}\text { Important child qualities: thrift , and saving } \\
\text { money and things }\end{array}$ & 255,656 \\
\hline $\begin{array}{l}\text { Important child qualities: tolerance and } \\
\text { respect for other people }\end{array}$ & $\begin{array}{l}\text { Important child qualities: tolerance and } \\
\text { respect for other people }\end{array}$ & 255,656 \\
\hline Important child qualities: unselfishness & Important child qualities: unselfishness & 252,238 \\
\hline $\begin{array}{l}\text { Justifiable: avoiding a fare on public } \\
\text { transport }\end{array}$ & $\begin{array}{l}\text { Justifiable: avoiding a fare on public } \\
\text { transport }\end{array}$ & 224,394 \\
\hline Justifiable: cheating on taxes & Justifiable: cheating on taxes & 232,012 \\
\hline $\begin{array}{l}\text { Justifiable: claiming government benefits } \\
\text { even if one is not entitled to them }\end{array}$ & Justifiable: claiming government benefits & 230,882 \\
\hline Justifiable: someone accepting a bribe & Justifiable: someone accepting a bribe & 243,824 \\
\hline $\begin{array}{l}\text { Most people can be trusted [highest } \\
\text { numerical value: you just can't be too } \\
\text { careful]) }\end{array}$ & $\begin{array}{l}\text { Lack of social capital (Most people can be } \\
\text { trusted [highest numerical value: you just } \\
\text { can't be too careful]) }\end{array}$ & 246,798 \\
\hline Neighbors: Immigrants/foreign workers & \begin{tabular}{|l|} 
[Rejecting] Neighbors: Immigrants/foreign \\
workers
\end{tabular} & 225,868 \\
\hline Neighbors: People of a different race & $\begin{array}{l}\text { [Rejecting] Neighbors: People of a different } \\
\text { race }\end{array}$ & 231,410 \\
\hline $\begin{array}{l}\text { Political system: having a democratic } \\
\text { political system }\end{array}$ & $\begin{array}{l}\text { Political system: (It’s very bad] having a } \\
\text { democratic political system }\end{array}$ & 193,889 \\
\hline Satisfaction with your life & Satisfaction with your life & 252,679 \\
\hline $\begin{array}{l}\text { self-positioning in political scale (scale 1- } \\
\text { left to 10-right) }\end{array}$ & $\begin{array}{l}\text { [Right wing] self-positioning in political } \\
\text { scale (scale 1-left to 10-right) }\end{array}$ & 180,041 \\
\hline $\begin{array}{l}\text { Sex (Gender) [in multivariate analysis: } \\
\text { female] (1=male; } 2=\text { female) }\end{array}$ & $\begin{array}{l}\text { Sex (Gender) [in multivariate analysis: } \\
\text { female] ( } 1=\text { male; } 2=\text { female) }\end{array}$ & 252,941 \\
\hline $\begin{array}{l}\text { University is more important for a boy } \\
\text { than for a girl }\end{array}$ & $\begin{array}{l}\text { Rejecting sexist position: University is more } \\
\text { important for a boy than for a girl }\end{array}$ & 207,655 \\
\hline
\end{tabular}


Table 3: Structure matrix - Promax with Kaiser normalization

\begin{tabular}{|c|c|c|c|c|c|c|c|c|c|}
\hline & $\begin{array}{l}\text { economic } \\
\text { permissi } \\
\text { veness }\end{array}$ & $\begin{array}{l}\text { tradition } \\
\text { al } \\
\text { religion }\end{array}$ & racism & $\begin{array}{c}\text { generatio } \\
\text { nal } \\
\text { educatio } \\
\text { n gaps }\end{array}$ & $\begin{array}{l}\text { distrust } \\
\text { of the } \\
\text { army } \\
\text { and the } \\
\text { press }\end{array}$ & $\begin{array}{l}\text { authorita } \\
\text { rian } \\
\text { character }\end{array}$ & $\begin{array}{l}\text { tolerance } \\
\text { and } \\
\text { respect }+ \\
\text { post- } \\
\text { materiali } \\
\text { sm }\end{array}$ & $\begin{array}{l}\text { the 'ego' } \\
\text { company } \\
\text { (indepen } \\
\text { dence + } \\
\text { selfishnes } \\
\text { s) }\end{array}$ & $\begin{array}{c}\text { rejection } \\
\text { of the } \\
\text { market } \\
\text { economy } \\
\text { and } \\
\text { democrac } \\
y\end{array}$ \\
\hline Age & -0.169 & -0.071 & -0.026 & -0.680 & -0.022 & -0.037 & 0.195 & 0.114 & -0.135 \\
\hline Competition good or harmful & 0.155 & -0.059 & 0.020 & -0.163 & 0.064 & -0.093 & -0.076 & -0.101 & 0.556 \\
\hline [No] Confidence: Armed Forces & 0.079 & -0.087 & -0.054 & 0.157 & 0.757 & -0.035 & 0.014 & 0.032 & 0.111 \\
\hline [No] Confidence: The Press & -0.016 & -0.090 & -0.076 & -0.020 & 0.759 & -0.010 & 0.120 & 0.039 & -0.007 \\
\hline Highest educational level attained & -0.041 & -0.098 & -0.094 & 0.648 & 0.078 & -0.195 & 0.165 & 0.158 & -0.136 \\
\hline How important is God in your life & -0.039 & 0.813 & 0.035 & -0.026 & -0.123 & 0.200 & -0.076 & -0.106 & 0.054 \\
\hline $\begin{array}{l}\text { [Never attend religious services. } \\
\text { Scale: ] How often do you attend } \\
\text { religious services }\end{array}$ & 0.018 & -0.800 & -0.064 & 0.033 & 0.138 & -0.119 & 0.108 & 0.080 & -0.021 \\
\hline $\begin{array}{l}\text { Immigrant policy (prevent people } \\
\text { from coming) }\end{array}$ & 0.003 & 0.089 & 0.302 & -0.191 & 0.107 & 0.227 & 0.097 & 0.044 & 0.095 \\
\hline $\begin{array}{l}\text { Important child qualities: } \\
\text { determination and perseverance }\end{array}$ & 0.002 & -0.232 & 0.015 & 0.282 & -0.003 & -0.104 & 0.114 & 0.114 & -0.192 \\
\hline $\begin{array}{l}\text { Important child qualities: feeling of } \\
\text { responsibility }\end{array}$ & -0.043 & -0.186 & -0.044 & 0.071 & -0.009 & -0.028 & 0.462 & 0.408 & 0.071 \\
\hline Important child qualities: hard work & 0.007 & 0.033 & -0.023 & -0.029 & -0.200 & 0.437 & -0.500 & 0.256 & -0.148 \\
\hline $\begin{array}{l}\text { Important child qualities: } \\
\text { imagination }\end{array}$ & 0.000 & -0.098 & -0.022 & 0.159 & 0.082 & -0.613 & -0.074 & 0.005 & 0.032 \\
\hline $\begin{array}{l}\text { Important child qualities: } \\
\text { independence }\end{array}$ & -0.020 & -0.133 & 0.057 & 0.207 & 0.067 & -0.508 & 0.007 & 0.353 & 0.031 \\
\hline Important child qualities: obedience & 0.030 & 0.268 & 0.035 & -0.158 & -0.043 & 0.300 & -0.201 & -0.562 & 0.031 \\
\hline $\begin{array}{l}\text { Important child qualities: religious } \\
\text { faith }\end{array}$ & -0.028 & 0.741 & 0.041 & -0.065 & -0.038 & 0.166 & -0.082 & -0.169 & -0.007 \\
\hline Important child qualities: thrift , and & 0.006 & -0.069 & 0.080 & -0.338 & -0.097 & 0.212 & -0.282 & 0.260 & 0.170 \\
\hline
\end{tabular}




\begin{tabular}{|c|c|c|c|c|c|c|c|c|c|}
\hline saving money and things & & & & & & & & & \\
\hline $\begin{array}{l}\text { Important child qualities: tolerance } \\
\text { and respect for other people }\end{array}$ & -0.064 & -0.029 & -0.104 & -0.009 & 0.026 & 0.033 & 0.623 & -0.032 & -0.072 \\
\hline $\begin{array}{l}\text { Important child qualities: } \\
\text { unselfishness }\end{array}$ & -0.008 & -0.013 & -0.024 & 0.063 & -0.016 & -0.107 & 0.131 & -0.644 & 0.031 \\
\hline $\begin{array}{l}\text { Justifiable: avoiding a fare on public } \\
\text { transport }\end{array}$ & 0.779 & -0.059 & -0.002 & 0.079 & 0.066 & 0.021 & -0.078 & -0.026 & 0.112 \\
\hline Justifiable: cheating on taxes & 0.791 & -0.103 & 0.020 & 0.047 & 0.084 & 0.018 & -0.089 & 0.021 & 0.026 \\
\hline $\begin{array}{l}\text { Justifiable: claiming government } \\
\text { benefits even if one is not entitled to } \\
\text { them }\end{array}$ & 0.716 & 0.006 & 0.059 & -0.003 & 0.017 & 0.041 & -0.112 & -0.053 & 0.132 \\
\hline $\begin{array}{l}\text { Justifiable: someone accepting a } \\
\text { bribe }\end{array}$ & 0.736 & 0.015 & 0.070 & 0.001 & 0.006 & 0.049 & -0.132 & -0.024 & 0.058 \\
\hline $\begin{array}{l}\text { Lack of social capital (Most people } \\
\text { can be trusted [highest numerical } \\
\text { value: you just can't be too careful]) }\end{array}$ & 0.037 & 0.149 & 0.073 & 0.085 & 0.164 & 0.562 & -0.238 & 0.058 & 0.121 \\
\hline $\begin{array}{l}\text { [Rejecting] Neighbors: } \\
\text { Immigrants/foreign workers }\end{array}$ & 0.039 & 0.025 & 0.845 & -0.064 & -0.076 & 0.045 & -0.113 & 0.018 & 0.003 \\
\hline $\begin{array}{l}\text { [Rejecting] Neighbors: People of a } \\
\text { different race }\end{array}$ & 0.043 & 0.059 & 0.827 & -0.055 & -0.115 & 0.026 & -0.161 & 0.006 & -0.008 \\
\hline $\begin{array}{l}\text { Political system: (It's very bad] } \\
\text { having a democratic political system }\end{array}$ & 0.175 & -0.106 & 0.097 & -0.087 & 0.136 & 0.246 & -0.239 & -0.009 & 0.458 \\
\hline $\begin{array}{l}\text { [Right wing] self-positioning in } \\
\text { political scale (scale 1-left to 10- } \\
\text { right) }\end{array}$ & 0.005 & 0.193 & 0.164 & -0.063 & -0.300 & 0.045 & -0.035 & 0.095 & -0.145 \\
\hline Sex (Gender) (1=male; 2=female) & -0.079 & 0.165 & -0.045 & 0.167 & -0.021 & -0.011 & 0.216 & 0.061 & 0.661 \\
\hline $\begin{array}{l}\text { Rejecting sexist position: University } \\
\text { is more important for a boy than for a } \\
\text { girl }\end{array}$ & -0.153 & -0.064 & -0.182 & 0.384 & 0.087 & -0.160 & 0.399 & -0.042 & 0.177 \\
\hline
\end{tabular}


Table 4: The correlations between the factors

\begin{tabular}{|c|c|c|c|c|c|c|c|c|}
\hline & & & & Matrix of comp & onents & & & \\
\hline & $\begin{array}{c}\text { Economic } \\
\text { permissiven } \\
\text { ess }\end{array}$ & $\begin{array}{c}\text { Traditional } \\
\text { religion }\end{array}$ & Racism & $\begin{array}{l}\text { Generational } \\
\text { education } \\
\text { gaps }\end{array}$ & $\begin{array}{l}\text { Distrust of } \\
\text { the army and } \\
\text { the press }\end{array}$ & $\begin{array}{l}\text { Authoritaria } \\
\text { n character }\end{array}$ & $\begin{array}{c}\text { Tolerance } \\
\text { and respect + } \\
\text { post- } \\
\text { materialism }\end{array}$ & $\begin{array}{c}\text { The 'ego' } \\
\text { company } \\
\text { (independenc } \\
\text { e + } \\
\text { selfishness) }\end{array}$ \\
\hline $\begin{array}{l}\text { Traditional } \\
\text { religion }\end{array}$ & -0.051 & & & & & & & \\
\hline Racism & 0.067 & 0.063 & & & & & & \\
\hline $\begin{array}{l}\text { Generational } \\
\text { education gaps }\end{array}$ & 0.010 & -0.036 & -0.103 & & & & & \\
\hline $\begin{array}{l}\text { Distrust of the } \\
\text { army and the press }\end{array}$ & 0.058 & -0.122 & -0.069 & 0.084 & & & & \\
\hline $\begin{array}{l}\text { Authoritarian } \\
\text { character }\end{array}$ & 0.055 & 0.190 & 0.064 & -0.192 & -0.042 & & & \\
\hline $\begin{array}{l}\text { Tolerance and } \\
\text { respect + post- } \\
\text { materialism }\end{array}$ & -0.175 & -0.090 & -0.144 & 0.119 & 0.072 & -0.276 & & \\
\hline $\begin{array}{l}\text { The ‘ego' } \\
\text { company } \\
\text { (independence + } \\
\text { selfishness) }\end{array}$ & -0.046 & -0.173 & 0.034 & 0.058 & -0.028 & 0.014 & -0.004 & \\
\hline $\begin{array}{l}\text { Rejection of the } \\
\text { market economy } \\
\text { and democracy }\end{array}$ & 0.093 & 0.034 & 0.018 & 0.030 & 0.117 & 0.045 & -0.005 & -0.027 \\
\hline
\end{tabular}


Table 5: The country means for the different new factors - mapping the new map of global values on earth

\begin{tabular}{|c|c|c|c|c|c|c|c|c|c|}
\hline & $\begin{array}{c}\text { Economic } \\
\text { permissive } \\
\text { ness }\end{array}$ & $\begin{array}{c}\text { Traditiona } \\
\text { l religion }\end{array}$ & Racism & $\begin{array}{c}\text { Generatio } \\
\text { nal } \\
\text { education } \\
\text { gaps }\end{array}$ & $\begin{array}{c}\text { Distrust of } \\
\text { the army } \\
\text { and the } \\
\text { press }\end{array}$ & $\begin{array}{c}\text { Authoritar } \\
\text { ian } \\
\text { character }\end{array}$ & $\begin{array}{c}\text { Tolerance } \\
\text { and } \\
\text { respect }+ \\
\text { post- } \\
\text { materialis } \\
\text { m } \\
\end{array}$ & $\begin{array}{c}\text { The 'ego' } \\
\text { company } \\
\text { (independe } \\
\text { nce + } \\
\text { selfishness } \\
\text { ) } \\
\end{array}$ & $\begin{array}{c}\text { Rejection } \\
\text { of the } \\
\text { market } \\
\text { economy } \\
\text { and } \\
\text { democracy }\end{array}$ \\
\hline Albania & 0.094 & -0.056 & -0.137 & -0.201 & 0.214 & 0.114 & -0.149 & -0.060 & -0.229 \\
\hline Argentina & -0.090 & 0.101 & -0.369 & -0.103 & 0.557 & 0.050 & 0.067 & 0.037 & 0.147 \\
\hline Australia & -0.340 & -0.569 & -0.387 & 0.004 & 0.275 & -0.516 & 0.554 & -0.241 & -0.166 \\
\hline Azerbaijan & 0.283 & -0.112 & -0.135 & 0.297 & 0.204 & 0.183 & -0.504 & 0.683 & -0.169 \\
\hline Bangladesh & -0.589 & 0.839 & 1.712 & -0.022 & -0.854 & -0.286 & -0.626 & 0.457 & -0.463 \\
\hline Belarus & 0.520 & -0.746 & -0.413 & -0.035 & 0.000 & 0.555 & -0.508 & 0.323 & 0.010 \\
\hline Bosnia and Herz. & -0.304 & -0.087 & 0.000 & 0.010 & -0.128 & -0.044 & -0.083 & -0.143 & -0.172 \\
\hline Brazil & 0.525 & 0.583 & -0.373 & -0.071 & -0.037 & 0.503 & -0.153 & -0.429 & 0.346 \\
\hline Bulgaria & -0.188 & -0.776 & -0.037 & 0.028 & -0.282 & 0.257 & -0.258 & 0.196 & -0.037 \\
\hline Chile & 0.225 & 0.147 & -0.139 & -0.131 & 0.223 & -0.131 & 0.209 & -0.316 & 0.457 \\
\hline Cyprus & -0.146 & 0.068 & 0.040 & 0.154 & -0.026 & 0.056 & 0.194 & -0.204 & -0.017 \\
\hline Czech Republic & 0.286 & -0.986 & 0.112 & -0.448 & 0.180 & 0.496 & -0.134 & 0.266 & -0.079 \\
\hline Dominican Rep. & -0.220 & 0.653 & -0.079 & 0.920 & 0.273 & 0.159 & 0.282 & 0.064 & -0.030 \\
\hline Estonia & 0.041 & -0.944 & -0.110 & 0.095 & 0.081 & 0.406 & -0.231 & 0.560 & -0.108 \\
\hline Ethiopia & -0.343 & 0.711 & -0.114 & 0.250 & 0.429 & -0.493 & -0.759 & -0.062 & 0.137 \\
\hline Finland & -0.162 & -0.664 & -0.046 & -0.168 & -0.059 & -0.680 & 0.811 & -0.018 & 0.187 \\
\hline Georgia & -0.054 & 0.179 & -0.080 & 0.208 & -0.075 & 0.335 & -0.228 & 0.510 & -0.178 \\
\hline Germany & -0.068 & -0.928 & -0.256 & -0.268 & 0.563 & -0.521 & 0.629 & 0.529 & 0.132 \\
\hline Ghana & -0.098 & 1.120 & 0.097 & 0.054 & -0.688 & 0.461 & -0.464 & -0.584 & -0.402 \\
\hline Guatemala & 0.535 & 0.806 & -0.354 & 0.125 & 0.310 & 0.236 & -0.120 & -0.546 & 0.424 \\
\hline Hong Kong & -0.048 & -0.856 & 1.801 & -0.193 & 0.008 & -0.236 & -0.575 & -0.164 & 0.222 \\
\hline Hungary & 0.467 & -0.716 & 0.256 & -0.132 & 0.353 & 0.057 & 0.455 & 0.074 & 0.075 \\
\hline India & -0.064 & 0.260 & 0.704 & -0.044 & -0.824 & 0.133 & -0.464 & -0.100 & -0.436 \\
\hline
\end{tabular}




\begin{tabular}{|c|c|c|c|c|c|c|c|c|c|}
\hline Indonesia & -0.412 & 1.032 & 0.591 & 0.268 & -0.366 & -0.218 & 0.017 & 0.182 & -0.110 \\
\hline Italy & -0.362 & 0.005 & -0.240 & 0.093 & 0.153 & -0.346 & 0.579 & 0.041 & -0.032 \\
\hline Jordan & -0.207 & 1.118 & 1.329 & 0.095 & -0.824 & -0.160 & 0.058 & -0.695 & -0.403 \\
\hline Kyrgyzstan & 0.117 & -0.185 & 0.047 & 0.433 & 0.041 & 0.239 & -0.409 & 0.419 & 0.175 \\
\hline Lithuania & 0.169 & -0.376 & 0.167 & 0.047 & -0.011 & 0.289 & -0.360 & 0.487 & 0.080 \\
\hline Macedonia & -0.134 & -0.191 & 0.362 & 0.056 & 0.508 & -0.035 & 0.458 & 0.002 & 0.058 \\
\hline Mali & 0.509 & 0.743 & 0.087 & -0.454 & -0.619 & 0.278 & -0.879 & -0.453 & -0.129 \\
\hline Moldova & 0.579 & -0.136 & -0.098 & -0.034 & 0.221 & 0.322 & -0.385 & 0.359 & 0.184 \\
\hline Morocco & -0.419 & 0.855 & -0.184 & -0.086 & -0.208 & 0.291 & -0.232 & -0.068 & -0.463 \\
\hline New Zealand & -0.371 & -0.675 & -0.419 & -0.085 & 0.125 & -0.702 & 0.601 & -0.090 & -0.323 \\
\hline Nigeria & -0.139 & 1.126 & 0.040 & 0.371 & 0.012 & 0.640 & -0.700 & -0.489 & -0.483 \\
\hline Norway & -0.271 & -0.813 & -0.288 & 0.165 & 0.151 & -1.324 & 0.989 & 0.165 & -0.088 \\
\hline Peru & 0.067 & 0.594 & -0.188 & 0.327 & 0.432 & 0.387 & -0.072 & -0.297 & -0.018 \\
\hline Philippines & 0.624 & 0.775 & 0.249 & 0.076 & -0.397 & 0.405 & -0.543 & -0.009 & 0.270 \\
\hline Puerto Rico & -0.335 & 0.865 & -0.216 & 0.231 & -0.043 & 0.181 & 0.472 & -0.163 & 0.005 \\
\hline Romania & -0.209 & 0.275 & 0.111 & 0.008 & -0.279 & 0.084 & -0.083 & 0.514 & -0.374 \\
\hline Russian Fed. & 0.339 & -1.070 & -0.251 & -0.174 & 0.099 & 0.777 & -0.462 & 0.363 & 0.259 \\
\hline Serbia & 1.266 & -0.152 & 0.285 & 0.078 & 0.445 & 0.143 & -0.194 & 0.100 & 0.140 \\
\hline Serbia and Mont. & -0.178 & -0.534 & -0.112 & -0.037 & 0.229 & 0.076 & -0.101 & 0.106 & -0.322 \\
\hline Slovakia & 0.476 & -0.176 & -0.016 & -0.411 & -0.042 & 0.494 & -0.139 & 0.221 & -0.105 \\
\hline Slovenia & 0.156 & -0.639 & 0.029 & 0.017 & 0.384 & -0.182 & 0.279 & 0.100 & 0.068 \\
\hline South Africa & -0.003 & 0.649 & 0.124 & 0.102 & 0.010 & 0.350 & -0.120 & -0.098 & 0.022 \\
\hline South Korea & -0.114 & -0.507 & 0.563 & 0.272 & -0.026 & -0.182 & -0.431 & 0.963 & 0.376 \\
\hline Spain & -0.135 & -0.554 & -0.372 & -0.265 & 0.264 & 0.039 & 0.075 & -0.158 & 0.126 \\
\hline Sweden & -0.109 & -1.036 & -0.443 & 0.045 & 0.311 & -1.205 & 1.067 & 0.133 & -0.137 \\
\hline Switzerland & -0.404 & -0.565 & -0.364 & 0.067 & 0.253 & -1.067 & 0.968 & 0.296 & -0.153 \\
\hline Taiwan & -0.206 & -0.705 & 0.191 & -0.140 & 0.325 & -0.057 & 0.180 & 0.563 & 0.210 \\
\hline Tanzania & -0.448 & 1.008 & 0.034 & -0.032 & -1.063 & 0.056 & -0.437 & -0.564 & -0.337 \\
\hline Thailand & 0.561 & 0.300 & 0.722 & -0.739 & 0.093 & -0.297 & -0.051 & -0.334 & 0.382 \\
\hline
\end{tabular}




\begin{tabular}{|c|c|c|c|c|c|c|c|c|c|}
\hline Turkey & -0.460 & 0.271 & 0.300 & 0.026 & -0.218 & 0.463 & -0.217 & 0.024 & 0.083 \\
\hline Uganda & 0.279 & 0.849 & -0.051 & 0.540 & -0.545 & 0.607 & -0.503 & -0.478 & -0.256 \\
\hline Ukraine & 0.553 & -0.504 & -0.219 & -0.016 & -0.020 & 0.345 & -0.435 & 0.230 & 0.080 \\
\hline United States & -0.292 & 0.292 & -0.250 & -0.050 & -0.076 & -0.207 & 0.348 & -0.038 & -0.155 \\
\hline Venezuela & -0.047 & 0.417 & 0.142 & 0.159 & -0.303 & 0.199 & 0.170 & -0.369 & 0.202 \\
\hline Viet Nam & -0.341 & -0.786 & 0.496 & -0.266 & -1.833 & -0.122 & -0.408 & 0.173 & -0.292 \\
\hline Zambia & 0.648 & 0.795 & 0.403 & 0.323 & -0.086 & 0.329 & -0.584 & -0.343 & -0.012 \\
\hline
\end{tabular}


Table 6: Country ranks of global values

\begin{tabular}{|c|c|c|c|c|c|c|c|c|c|}
\hline & $\begin{array}{c}\text { Avoiding } \\
\text { economic } \\
\text { permissiven } \\
\text { ess }\end{array}$ & $\begin{array}{l}\text { Traditiona } \\
\text { I religion }\end{array}$ & $\begin{array}{l}\text { Avoiding } \\
\text { racism }\end{array}$ & $\begin{array}{c}\text { Generatio } \\
\text { nal } \\
\text { education } \\
\text { gaps, }\end{array}$ & $\begin{array}{l}\text { Avoiding } \\
\text { the } \\
\text { distrust of } \\
\text { the army } \\
\text { and the } \\
\text { press }\end{array}$ & $\begin{array}{l}\text { Avoiding } \\
\text { the } \\
\text { authorita } \\
\text { rian } \\
\text { character }\end{array}$ & $\begin{array}{l}\text { Tolerance } \\
\text { and } \\
\text { respect }+ \\
\text { post- } \\
\text { materialis } \\
\text { m }\end{array}$ & $\begin{array}{c}\text { The ‘ego' } \\
\text { company } \\
\text { (rejection } \\
\text { of } \\
\text { obedience } \\
+ \\
\text { unselfishne } \\
\text { ss) } \\
\end{array}$ & $\begin{array}{c}\text { Avoiding } \\
\text { the rejection } \\
\text { of the } \\
\text { market } \\
\text { economy } \\
\text { and } \\
\text { democracy }\end{array}$ \\
\hline Albania & 43 & 35 & 24 & 56 & 47 & 33 & 37 & 37 & 12 \\
\hline Argentina & 32 & 32 & 9 & 49 & 66 & 28 & 23 & 30 & 51 \\
\hline Armenia & 54 & 46 & 37 & 11 & 22 & 48 & 62 & 16 & 31 \\
\hline Australia & 12 & 51 & 6 & 38 & 54 & 7 & 8 & 49 & 17 \\
\hline Azerbaijan & 50 & 37 & 25 & 7 & 46 & 38 & 57 & 2 & 16 \\
\hline Bangladesh & 1 & 11 & 66 & 40 & 3 & 13 & 63 & 10 & 3 \\
\hline Belarus & 59 & 58 & 5 & 43 & 31 & 62 & 58 & 14 & 37 \\
\hline Bosnia and Hetz. & 14 & 36 & 39 & 36 & 17 & 24 & 29 & 44 & 15 \\
\hline Brazil & 60 & 21 & 7 & 46 & 26 & 60 & 38 & 57 & 61 \\
\hline Bulgaria & 23 & 59 & 36 & 33 & 12 & 42 & 44 & 20 & 28 \\
\hline Burkina Faso & 45 & 8 & 2 & 57 & 14 & 55 & 66 & 67 & 13 \\
\hline Canada & 16 & 41 & 3 & 32 & 35 & 9 & 9 & 43 & 35 \\
\hline Chile & 48 & 31 & 23 & 50 & 49 & 20 & 18 & 52 & 66 \\
\hline Cyprus & 25 & 33 & 42 & 16 & 27 & 30 & 19 & 48 & 33 \\
\hline Czech Republic & 51 & 65 & 48 & 64 & 45 & 59 & 33 & 17 & 27 \\
\hline Dominican Republic & 19 & 18 & 32 & 1 & 52 & 36 & 16 & 28 & 30 \\
\hline Estonia & 40 & 64 & 28 & 20 & 37 & 54 & 42 & 5 & 24 \\
\hline Ethiopia & 10 & 17 & 27 & 10 & 61 & 8 & 65 & 38 & 49 \\
\hline Finland & 24 & 53 & 35 & 53 & 23 & 5 & 4 & 34 & 54 \\
\hline Georgia & 35 & 30 & 30 & 13 & 20 & 49 & 41 & 8 & 14 \\
\hline
\end{tabular}




\begin{tabular}{|c|c|c|c|c|c|c|c|c|c|}
\hline Germany & 33 & 63 & 15 & 62 & 67 & 6 & 5 & 6 & 48 \\
\hline Ghana & 31 & 2 & 46 & 27 & 6 & 56 & 55 & 64 & 6 \\
\hline Guatemala & 61 & 12 & 11 & 17 & 55 & 40 & 31 & 62 & 65 \\
\hline Hong Kong & 37 & 62 & 67 & 55 & 32 & 14 & 60 & 47 & 57 \\
\hline Hungary & 53 & 57 & 55 & 51 & 59 & 31 & 12 & 27 & 43 \\
\hline India & 34 & 29 & 63 & 44 & 4 & 34 & 54 & 42 & 4 \\
\hline Indonesia & 6 & 4 & 62 & 9 & 10 & 15 & 26 & 21 & 23 \\
\hline Italy & 9 & 34 & 18 & 21 & 44 & 11 & 7 & 29 & 29 \\
\hline Jordan & 21 & 3 & 65 & 19 & 5 & 19 & 24 & 65 & 5 \\
\hline Kyrgyzstan & 44 & 42 & 44 & 3 & 36 & 41 & 49 & 11 & 52 \\
\hline Latvia & 56 & 56 & 26 & 30 & 57 & 61 & 36 & 4 & 38 \\
\hline Lithuania & 47 & 44 & 51 & 29 & 30 & 44 & 45 & 9 & 44 \\
\hline Macedonia & 28 & 43 & 58 & 26 & 65 & 25 & 11 & 32 & 40 \\
\hline Mali & 58 & 16 & 45 & 66 & 7 & 43 & 67 & 58 & 22 \\
\hline Mexico & 57 & 24 & 53 & 24 & 39 & 22 & 34 & 56 & 60 \\
\hline Moldova & 64 & 38 & 29 & 42 & 48 & 46 & 46 & 13 & 53 \\
\hline Morocco & 5 & 9 & 22 & 48 & 16 & 45 & 43 & 39 & 2 \\
\hline New Zealand & 8 & 54 & 4 & 47 & 42 & 4 & 6 & 40 & 9 \\
\hline Nigeria & 26 & 1 & 43 & 4 & 34 & 65 & 64 & 61 & 1 \\
\hline Norway & 17 & 61 & 14 & 14 & 43 & 1 & 2 & 23 & 26 \\
\hline Peru & 41 & 20 & 21 & 5 & 62 & 52 & 28 & 51 & 32 \\
\hline Philippines & 65 & 15 & 54 & 23 & 9 & 53 & 59 & 33 & 59 \\
\hline Poland & 36 & 23 & 31 & 65 & 38 & 27 & 15 & 36 & 67 \\
\hline Puerto Rico & 13 & 7 & 20 & 12 & 24 & 37 & 10 & 46 & 36 \\
\hline Romania & 20 & 27 & 47 & 37 & 13 & 32 & 30 & 7 & 7 \\
\hline Russian Federation & 52 & 67 & 16 & 54 & 41 & 67 & 53 & 12 & 58 \\
\hline Serbia & 67 & 39 & 56 & 22 & 63 & 35 & 39 & 25 & 50 \\
\hline Slovakia & 55 & 40 & 38 & 63 & 25 & 58 & 35 & 19 & 25 \\
\hline
\end{tabular}




\begin{tabular}{|c|c|c|c|c|c|c|c|c|c|}
\hline Slovenia & 46 & 52 & 40 & 35 & 60 & 18 & 17 & 26 & 42 \\
\hline South Africa & 39 & 19 & 49 & 18 & 33 & 51 & 32 & 41 & 39 \\
\hline South Korea & 29 & 48 & 61 & 8 & 28 & 17 & 50 & 1 & 62 \\
\hline Spain & 27 & 49 & 8 & 60 & 51 & 26 & 22 & 45 & 47 \\
\hline Sweden & 30 & 66 & 1 & 31 & 56 & 2 & 1 & 24 & 21 \\
\hline Switzerland & 7 & 50 & 10 & 25 & 50 & 3 & 3 & 15 & 19 \\
\hline Taiwan & 22 & 55 & 52 & 52 & 58 & 23 & 20 & 3 & 56 \\
\hline Tanzania & 4 & 5 & 41 & 41 & 2 & 29 & 52 & 63 & 8 \\
\hline Thailand & 63 & 25 & 64 & 67 & 40 & 12 & 27 & 53 & 63 \\
\hline Trinidad and Tobago & 42 & 13 & 13 & 59 & 64 & 63 & 25 & 50 & 41 \\
\hline Turkey & 3 & 28 & 57 & 34 & 15 & 57 & 40 & 31 & 46 \\
\hline Uganda & 49 & 10 & 34 & 2 & 8 & 64 & 56 & 60 & 11 \\
\hline Ukraine & 62 & 47 & 19 & 39 & 29 & 50 & 51 & 18 & 45 \\
\hline United States & 15 & 26 & 17 & 45 & 19 & 16 & 14 & 35 & 18 \\
\hline Uruguay & 18 & 45 & 12 & 58 & 53 & 10 & 13 & 59 & 64 \\
\hline Venezuela & 38 & 22 & 50 & 15 & 11 & 39 & 21 & 55 & 55 \\
\hline Viet Nam & 11 & 60 & 60 & 61 & 1 & 21 & 48 & 22 & 10 \\
\hline Zambia & 66 & 14 & 59 & 6 & 18 & 47 & 61 & 54 & 34 \\
\hline Zimbabwe & 2 & 6 & 33 & 28 & 21 & 66 & 47 & 66 & 20 \\
\hline
\end{tabular}


Table 7: The rankings of the best and the worst ranked regions in the $\mathrm{EU}$, the candidate and potential candidate countries

\begin{tabular}{|c|c|c|c|c|c|c|c|c|c|c|}
\hline $\begin{array}{l}\text { Region where the } \\
\text { interview was } \\
\text { conducted }\end{array}$ & Country & $\begin{array}{l}\text { Avoiding } \\
\text { economic } \\
\text { permissiv } \\
\text { eness }\end{array}$ & $\begin{array}{l}\text { Avoiding } \\
\text { racism }\end{array}$ & $\begin{array}{l}\text { Avoiding } \\
\text { distrust of } \\
\text { the army } \\
\text { and the } \\
\text { press }\end{array}$ & $\begin{array}{l}\text { Avoiding } \\
\text { the } \\
\text { authoritar } \\
\text { ian } \\
\text { character }\end{array}$ & $\begin{array}{l}\text { Tolerance } \\
\text { and } \\
\text { respect }+ \\
\text { post- } \\
\text { materialis } \\
\text { m }\end{array}$ & $\begin{array}{l}\text { Avoiding } \\
\text { the } \\
\text { rejection of } \\
\text { market } \\
\text { economy } \\
\text { and } \\
\text { democracy }\end{array}$ & $\begin{array}{c}\text { Regional } \\
\text { develop } \\
\text { ment } \\
\text { index }\end{array}$ & $\begin{array}{l}\text { World } \\
\text { Rank }\end{array}$ & $\begin{array}{c}\text { Rank in } \\
\text { the } \\
\text { enlarged } \\
\text { EU }\end{array}$ \\
\hline Skåne & Sweden & 0.745 & 0.928 & 0.309 & 0.999 & 0.971 & 0.584 & 0.756 & 3 & 1 \\
\hline Lappi & Finland & 0.764 & 0.910 & 0.473 & 0.824 & 0.893 & 0.468 & 0.722 & 10 & 5 \\
\hline Jönköping & Sweden & 0.756 & 0.880 & 0.238 & 0.781 & 0.979 & 0.528 & 0.694 & 21 & 9 \\
\hline Dolj & Romania & 0.889 & 0.928 & 0.487 & 0.294 & 0.686 & 0.859 & 0.690 & 22 & 10 \\
\hline Rheinland-Pfalz & Germany & 0.659 & 0.893 & 0.282 & 0.743 & 0.910 & 0.510 & 0.666 & 33 & 13 \\
\hline Emilia-Romagna & Italy & 0.866 & 0.843 & 0.281 & 0.586 & 0.790 & 0.569 & 0.656 & 43 & 14 \\
\hline Montana & Portugal & 0.860 & 0.906 & 0.330 & 0.430 & 0.681 & 0.583 & 0.632 & 71 & 23 \\
\hline Central Serbia & Serbia and Mont. & 0.807 & 0.887 & 0.381 & 0.325 & 0.618 & 0.629 & 0.608 & 97 & 36 \\
\hline Kyrenia & Cyprus & 0.830 & 0.760 & 0.460 & 0.446 & 0.585 & 0.525 & 0.601 & 108 & 42 \\
\hline Castilla Leon & Spain & 0.894 & 0.891 & 0.330 & 0.387 & 0.626 & 0.447 & 0.596 & 115 & 49 \\
\hline Campania & Italy & 0.770 & 0.834 & 0.255 & 0.486 & 0.786 & 0.354 & 0.581 & 138 & 58 \\
\hline Eastern Black Sea & Turkey & 0.926 & 0.740 & 0.446 & 0.138 & 0.693 & 0.534 & 0.579 & 141 & 60 \\
\hline Metropolitana & Portugal & 0.742 & 0.792 & 0.360 & 0.317 & 0.809 & 0.394 & 0.569 & 157 & 68 \\
\hline Osrednja Slovenska & Slovenia & 0.635 & 0.799 & 0.204 & 0.546 & 0.743 & 0.463 & 0.565 & 169 & 73 \\
\hline Ruse & Bulgaria & 0.809 & 0.862 & 0.459 & 0.256 & 0.550 & 0.427 & 0.561 & 178 & 78 \\
\hline Tartumaa & Estonia & 0.808 & 0.691 & 0.431 & 0.263 & 0.504 & 0.626 & 0.554 & 193 & 84 \\
\hline Ohridski & Macedonia & 0.780 & 0.728 & 0.152 & 0.446 & 0.687 & 0.468 & 0.544 & 222 & 99 \\
\hline Tirana & Albania & 0.644 & 0.923 & 0.217 & 0.411 & 0.483 & 0.550 & 0.538 & 233 & 104 \\
\hline Thueringen & Germany & 0.750 & 0.818 & 0.109 & 0.474 & 0.714 & 0.335 & 0.533 & 244 & 110 \\
\hline Prague & Czech Rep & 0.547 & 0.759 & 0.295 & 0.263 & 0.693 & 0.619 & 0.530 & 257 & 115 \\
\hline Center & Albania & 0.614 & 0.743 & 0.355 & 0.312 & 0.546 & 0.602 & 0.529 & 258 & 116 \\
\hline Arges & Romania & 0.212 & 0.735 & 0.617 & 0.433 & 0.424 & 0.736 & 0.526 & 266 & 121 \\
\hline Central-Hungary & Hungary & 0.528 & 0.680 & 0.220 & 0.346 & 0.814 & 0.510 & 0.516 & 289 & 130 \\
\hline Vaasan & Finland & 0.733 & 0.669 & 0.292 & 0.468 & 0.733 & 0.190 & 0.514 & 295 & 132 \\
\hline Sofia-province & Bulgaria & 0.677 & 0.762 & 0.395 & 0.323 & 0.471 & 0.453 & 0.513 & 298 & 134 \\
\hline
\end{tabular}




\begin{tabular}{|c|c|c|c|c|c|c|c|c|c|c|}
\hline Bratislava County & Slovakia & 0.425 & 0.747 & 0.336 & 0.303 & 0.699 & 0.522 & 0.505 & 323 & 138 \\
\hline Vilnius & Lithuania & 0.699 & 0.782 & 0.363 & 0.258 & 0.454 & 0.447 & 0.501 & 335 & 140 \\
\hline Pomurska & Slovenia & 0.588 & 0.775 & 0.233 & 0.375 & 0.664 & 0.366 & 0.500 & 337 & 142 \\
\hline Poloski & Macedonia & 0.661 & 0.842 & 0.077 & 0.274 & 0.604 & 0.498 & 0.493 & 362 & 149 \\
\hline South-Danubian & Hungary & 0.639 & 0.710 & 0.260 & 0.307 & 0.702 & 0.285 & 0.484 & 374 & 153 \\
\hline Pais Vasco & Spain & 0.505 & 0.878 & 0.175 & 0.388 & 0.550 & 0.402 & 0.483 & 378 & 155 \\
\hline Isa-Virumaa & Estonia & 0.603 & 0.839 & 0.286 & 0.204 & 0.411 & 0.544 & 0.481 & 383 & 157 \\
\hline Daugavpils & Latvia & 0.707 & 0.888 & 0.242 & 0.126 & 0.418 & 0.500 & 0.480 & 386 & 158 \\
\hline Limassol & Cyprus & 0.675 & 0.723 & 0.390 & 0.299 & 0.585 & 0.188 & 0.477 & 396 & 160 \\
\hline Northern Slovakia & Slovakia & 0.471 & 0.769 & 0.338 & 0.199 & 0.507 & 0.506 & 0.465 & 419 & 167 \\
\hline Central Anatolia & Turkey & 0.821 & 0.317 & 0.509 & 0.318 & 0.361 & 0.400 & 0.455 & 436 & 168 \\
\hline Kaunas & Lithuania & 0.551 & 0.711 & 0.337 & 0.323 & 0.423 & 0.308 & 0.442 & 465 & 171 \\
\hline $\begin{array}{l}\text { Západoèeský kraj - } \\
\text { West Bohemia - }\end{array}$ & Czech Rep. & 0.499 & 0.642 & 0.278 & 0.195 & 0.448 & 0.490 & 0.426 & 482 & 172 \\
\hline Ziemelu reg. & Latvia & 0.355 & 0.881 & 0.169 & 0.193 & 0.423 & 0.488 & 0.418 & 488 & 174 \\
\hline South East Serbia & Serbia and Mont. & 0.040 & 0.662 & 0.244 & 0.262 & 0.505 & 0.309 & 0.337 & 509 & 176 \\
\hline
\end{tabular}


Table 8: The rank of Turkish regions in the geography of global values

\begin{tabular}{|c|c|c|c|}
\hline Factor & $\begin{array}{c}\text { Factor } \\
\text { number }\end{array}$ & $\begin{array}{c}\text { Global } \\
\text { rank }\end{array}$ & $\begin{array}{l}\text { Region where the } \\
\text { interview was } \\
\text { conducted }\end{array}$ \\
\hline $\begin{array}{l}\text { higher education of the younger generation (education gap } \\
\text { between the generations) }\end{array}$ & 4 & 49 & Aegean \\
\hline authoritarian character & 6 & 127 & Aegean \\
\hline rejection of the market economy and democracy & 9 & 133 & Aegean \\
\hline the 'ego' company (rejection of obedience + unselfishness) & 8 & 140 & Aegean \\
\hline traditional religion & 2 & 299 & Aegean \\
\hline tolerance and respect + postmaterialism & 7 & 339 & Aegean \\
\hline distrust of the army and the press & 5 & 364 & Aegean \\
\hline racism & 3 & 373 & Aegean \\
\hline permissiveness, pessimism & 1 & 383 & Aegean \\
\hline racism & 3 & 18 & Central Anatolia \\
\hline the 'ego' company (rejection of obedience + unselfishness) & 8 & 149 & Central Anatolia \\
\hline traditional religion & 2 & 154 & Central Anatolia \\
\hline rejection of the market economy and democracy & 9 & 167 & Central Anatolia \\
\hline authoritarian character & 6 & 236 & Central Anatolia \\
\hline $\begin{array}{l}\text { higher education of the younger generation (education gap } \\
\text { between the generations) }\end{array}$ & 4 & 380 & Central Anatolia \\
\hline permissiveness, pessimism & 1 & 398 & Central Anatolia \\
\hline distrust of the army and the press & 5 & 454 & Central Anatolia \\
\hline tolerance and respect + postmaterialism & 7 & 457 & Central Anatolia \\
\hline authoritarian character & 6 & 59 & East Central Anatolia \\
\hline traditional religion & 2 & 136 & East Central Anatolia \\
\hline racism & 3 & 143 & East Central Anatolia \\
\hline tolerance and respect + postmaterialism & 7 & 200 & East Central Anatolia \\
\hline $\begin{array}{l}\text { higher education of the younger generation (education gap } \\
\text { between the generations) }\end{array}$ & 4 & 254 & East Central Anatolia \\
\hline the 'ego' company (rejection of obedience + unselfishness) & 8 & 255 & East Central Anatolia \\
\hline distrust of the army and the press & 5 & 395 & East Central Anatolia \\
\hline rejection of the market economy and democracy & 9 & 395 & East Central Anatolia \\
\hline permissiveness, pessimism & 1 & 510 & East Central Anatolia \\
\hline authoritarian character & 6 & 41 & Eastern Black Sea \\
\hline tolerance and respect + postmaterialism & 7 & 132 & Eastern Black Sea \\
\hline $\begin{array}{l}\text { higher education of the younger generation (education gap } \\
\text { between the generations) }\end{array}$ & 4 & 142 & Eastern Black Sea \\
\hline racism & 3 & 155 & Eastern Black Sea \\
\hline traditional religion & 2 & 170 & Eastern Black Sea \\
\hline the 'ego' company (rejection of obedience + unselfishness) & 8 & 346 & Eastern Black Sea \\
\hline rejection of the market economy and democracy & 9 & 354 & Eastern Black Sea \\
\hline distrust of the army and the press & 5 & 403 & Eastern Black Sea \\
\hline permissiveness, pessimism & 1 & 494 & Eastern Black Sea \\
\hline the 'ego' company (rejection of obedience + unselfishness) & 8 & 105 & Eastern Marmara \\
\hline $\begin{array}{l}\text { higher education of the younger generation (education gap } \\
\text { between the generations) }\end{array}$ & 4 & 143 & Eastern Marmara \\
\hline authoritarian character & 6 & 161 & Eastern Marmara \\
\hline traditional religion & 2 & 172 & Eastern Marmara \\
\hline racism & 3 & 179 & Eastern Marmara \\
\hline rejection of the market economy and democracy & 9 & 244 & Eastern Marmara \\
\hline tolerance and respect + postmaterialism & 7 & 249 & Eastern Marmara \\
\hline distrust of the army and the press & 5 & 438 & Eastern Marmara \\
\hline
\end{tabular}




\begin{tabular}{|c|c|c|c|}
\hline permissiveness, pessimism & 1 & 487 & Eastern Marmara \\
\hline authoritarian character & 6 & 124 & Istanbul \\
\hline racism & 3 & 128 & Istanbul \\
\hline rejection of the market economy and democracy & 9 & 163 & Istanbul \\
\hline traditional religion & 2 & 164 & Istanbul \\
\hline tolerance and respect + postmaterialism & 7 & 247 & Istanbul \\
\hline the 'ego' company (rejection of obedience + unselfishness) & 8 & 281 & Istanbul \\
\hline $\begin{array}{l}\text { higher education of the younger generation (education gap } \\
\text { between the generations) }\end{array}$ & 4 & 285 & Istanbul \\
\hline distrust of the army and the press & 5 & 341 & Istanbul \\
\hline permissiveness, pessimism & 1 & 479 & Istanbul \\
\hline racism & 3 & 84 & Mediterranean \\
\hline authoritarian character & 6 & 103 & Mediterranean \\
\hline traditional religion & 2 & 197 & Mediterranean \\
\hline rejection of the market economy and democracy & 9 & 236 & Mediterranean \\
\hline the 'ego' company (rejection of obedience + unselfishness) & 8 & 306 & Mediterranean \\
\hline permissiveness, pessimism & 1 & 392 & Mediterranean \\
\hline tolerance and respect + postmaterialism & 7 & 392 & Mediterranean \\
\hline distrust of the army and the press & 5 & 399 & Mediterranean \\
\hline $\begin{array}{l}\text { higher education of the younger generation (education } \\
\text { gap between the generations) }\end{array}$ & 4 & 404 & Mediterranean \\
\hline racism & 3 & 102 & North Eastern Anatolia \\
\hline $\begin{array}{l}\text { higher education of the younger generation (education gap } \\
\text { between the generations) }\end{array}$ & 4 & 115 & North Eastern Anatolia \\
\hline rejection of the market economy and democracy & 9 & 176 & North Eastern Anatolia \\
\hline traditional religion & 2 & 182 & North Eastern Anatolia \\
\hline distrust of the army and the press & 5 & 182 & North Eastern Anatolia \\
\hline authoritarian character & 6 & 203 & North Eastern Anatolia \\
\hline tolerance and respect + postmaterialism & 7 & 299 & North Eastern Anatolia \\
\hline the 'ego’ company (rejection of obedience + unselfishness) & 8 & 450 & North Eastern Anatolia \\
\hline permissiveness, pessimism & $\mathbf{1}$ & 466 & $\begin{array}{l}\text { North Eastern } \\
\text { Anatolia }\end{array}$ \\
\hline racism & 3 & 85 & South Eastern Anatolia \\
\hline authoritarian character & 6 & 118 & South Eastern Anatolia \\
\hline distrust of the army and the press & 5 & 132 & South Eastern Anatolia \\
\hline rejection of the market economy and democracy & 9 & 158 & South Eastern Anatolia \\
\hline $\begin{array}{l}\text { higher education of the younger generation (education gap } \\
\text { between the generations) }\end{array}$ & 4 & 196 & South Eastern Anatolia \\
\hline the 'ego' company (rejection of obedience + unselfishness) & 8 & 211 & South Eastern Anatolia \\
\hline traditional religion & 2 & 262 & South Eastern Anatolia \\
\hline tolerance and respect + postmaterialism & 7 & 326 & South Eastern Anatolia \\
\hline permissiveness, pessimism & 1 & 332 & South Eastern Anatolia \\
\hline authoritarian character & 6 & 55 & Western Anatolia \\
\hline racism & 3 & 108 & Western Anatolia \\
\hline rejection of the market economy and democracy & 9 & 123 & Western Anatolia \\
\hline traditional religion & 2 & 177 & Western Anatolia \\
\hline $\begin{array}{l}\text { higher education of the younger generation (education gap } \\
\text { between the generations) }\end{array}$ & 4 & 206 & Western Anatolia \\
\hline tolerance and respect + postmaterialism & 7 & 270 & Western Anatolia \\
\hline distrust of the army and the press & 5 & 286 & Western Anatolia \\
\hline the ‘ego’ company (rejection of obedience + unselfishness) & 8 & 357 & Western Anatolia \\
\hline permissiveness, pessimism & 1 & 484 & Western Anatolia \\
\hline racism & 3 & 31 & Western Black Sea \\
\hline authoritarian character & 6 & 143 & Western Black Sea \\
\hline
\end{tabular}




\begin{tabular}{|l|c|c|l|}
\hline traditional religion & 2 & 158 & Western Black Sea \\
\hline tolerance and respect + postmaterialism & 7 & 183 & Western Black Sea \\
\hline the ‘ego' company (rejection of obedience + unselfishness) & 8 & 319 & Western Black Sea \\
\hline $\begin{array}{l}\text { higher education of the younger generation (education gap } \\
\text { between the generations) }\end{array}$ & 4 & 369 & Western Black Sea \\
\hline rejection of the market economy and democracy & 9 & 397 & Western Black Sea \\
\hline distrust of the army and the press & $\mathbf{5}$ & $\mathbf{4 7 1}$ & Western Black Sea \\
\hline permissiveness, pessimism & $\mathbf{1}$ & $\mathbf{5 0 7}$ & Western Black Sea \\
\hline authoritarian character & $\mathbf{6}$ & $\mathbf{1 3}$ & Western Marmara \\
\hline racism & 3 & 68 & Western Marmara \\
\hline traditional religion & 2 & 88 & Western Marmara \\
\hline rejection of the market economy and democracy & 9 & 93 & Western Marmara \\
\hline the ‘ego' company (rejection of obedience + unselfishness) & 8 & 308 & Western Marmara \\
\hline tolerance and respect + postmaterialism & 7 & 334 & Western Marmara \\
\hline distrust of the army and the press & $\mathbf{5}$ & $\mathbf{4 6 6}$ & Western Marmara \\
\hline $\begin{array}{l}\text { higher education of the younger generation (education gap } \\
\text { between the generations) }\end{array}$ & 4 & 497 & Western Marmara \\
\hline permissiveness, pessimism & $\mathbf{1}$ & $\mathbf{5 0 5}$ & Western Marmara \\
\hline
\end{tabular}


Table 9: The rankings of the countries on a new Global Value Development Index

\begin{tabular}{|c|c|c|}
\hline Country & $\begin{array}{c}\begin{array}{c}\text { Value Development } \\
\text { Index }\end{array} \\
\end{array}$ & $\begin{array}{l}\text { Global Rank Value } \\
\text { Development Index }\end{array}$ \\
\hline Switzerland & 3.84 & 1 \\
\hline Norway & 3.77 & 2 \\
\hline Sweden & 3.41 & 3 \\
\hline New Zealand & 3.33 & 4 \\
\hline Australia & 2.57 & 5 \\
\hline Canada & 2.50 & 6 \\
\hline Vietnam & 2.38 & 7 \\
\hline Tanzania & 2.23 & 8 \\
\hline Italy & 2.23 & 9 \\
\hline Finland & 2.11 & 10 \\
\hline United States & 2.06 & 11 \\
\hline Morocco & 1.50 & 12 \\
\hline \begin{tabular}{|l|} 
Uruguay \\
\end{tabular} & 1.44 & 13 \\
\hline Germany & 1.08 & 14 \\
\hline Bosnia and Herzegovina & 1.07 & 15 \\
\hline Indonesia & 0.91 & 16 \\
\hline Romania & 0.89 & 17 \\
\hline Spain & 0.54 & 18 \\
\hline Cyprus & 0.51 & 19 \\
\hline Dominican Republic & 0.50 & 20 \\
\hline Bulgaria & 0.34 & 21 \\
\hline Ghana & 0.31 & 22 \\
\hline Zimbabwe & 0.26 & 23 \\
\hline Ethiopia & 0.08 & 24 \\
\hline \begin{tabular}{|l|} 
Turkey \\
\end{tabular} & 0.06 & 25 \\
\hline Venezuela & 0.03 & 26 \\
\hline Jordan & 0.01 & 27 \\
\hline Argentina & 0.00 & 28 \\
\hline Poland & -0.07 & 29 \\
\hline Georgia & -0.11 & 30 \\
\hline Bangladesh & -0.20 & 31 \\
\hline India & -0.20 & 32 \\
\hline Albania & -0.36 & 33 \\
\hline Macedonia & -0.43 & 34 \\
\hline Slovenia & -0.47 & 35 \\
\hline Burkina Faso & -0.51 & 36 \\
\hline Estonia & -0.66 & 37 \\
\hline Chile & -0.69 & 38 \\
\hline South Africa & -0.79 & 39 \\
\hline Nigeria & -0.81 & 40 \\
\hline Peru & -0.94 & 41 \\
\hline Uganda & -0.95 & 42 \\
\hline Trinidad and Tobago & -1.04 & 43 \\
\hline
\end{tabular}




\begin{tabular}{|l|l|l|}
\hline Korea, South & -1.28 & 44 \\
\hline Kyrgyzstan & -1.36 & 45 \\
\hline Azerbaijan & -1.37 & 46 \\
\hline Lithuania & -1.53 & 47 \\
\hline Hungary & -1.69 & 48 \\
\hline Slovakia & -1.76 & 49 \\
\hline Brazil & -1.77 & 50 \\
\hline Czech Republic & -1.81 & 51 \\
\hline Mali & -1.83 & 52 \\
\hline Belarus & -1.87 & 53 \\
\hline Ukraine & -1.99 & 54 \\
\hline Guatemala & -2.00 & 55 \\
\hline Mexico & -2.10 & 56 \\
\hline Armenia & -2.13 & 57 \\
\hline Latvia & -2.22 & 58 \\
\hline Russia & -2.27 & 59 \\
\hline Moldova & -2.59 & 60 \\
\hline Thailand & -2.85 & 61 \\
\hline Philippines & -2.86 & 62 \\
\hline Zambia & -3.25 & 63 \\
\hline
\end{tabular}


Table 10: Ranking of the countries on tolerance and democracy indicators

\begin{tabular}{|c|c|c|c|c|c|c|}
\hline & $\begin{array}{c}\text { avoiding } \\
\text { racism }\end{array}$ & $\begin{array}{l}\text { absence of } \\
\text { an } \\
\text { authoritari } \\
\text { an } \\
\text { character }\end{array}$ & $\begin{array}{c}\text { tolerance } \\
\text { and respect } \\
+ \text { post- } \\
\text { materialism }\end{array}$ & $\begin{array}{l}\text { avoiding } \\
\text { the } \\
\text { rejection of } \\
\text { the market } \\
\text { economy } \\
\text { and } \\
\text { democracy }\end{array}$ & $\begin{array}{c}\text { Overall } \\
\text { Liberal } \\
\text { Values } \\
\text { Developme } \\
\text { nt Index }\end{array}$ & $\begin{array}{c}\text { Global } \\
\text { Rank Value } \\
\text { Developme } \\
\text { nt Index }\end{array}$ \\
\hline Sweden & 0.748 & 1.433 & 1.220 & 0.139 & 3.539 & 1 \\
\hline Norway & 0.486 & 1.574 & 1.130 & 0.089 & 3.280 & 2 \\
\hline Switzerland & 0.614 & 1.269 & 1.106 & 0.155 & 3.144 & 3 \\
\hline New Zealand & 0.707 & 0.835 & 0.687 & 0.327 & 2.556 & 4 \\
\hline Australia & 0.653 & 0.614 & 0.633 & 0.168 & 2.068 & 5 \\
\hline Canada & 0.716 & 0.520 & 0.570 & 0.003 & 1.809 & 6 \\
\hline Germany & 0.432 & 0.619 & 0.719 & -0.134 & 1.637 & 7 \\
\hline Finland & 0.078 & 0.809 & 0.927 & -0.189 & 1.624 & 8 \\
\hline Italy & 0.405 & 0.411 & 0.662 & 0.032 & 1.511 & 9 \\
\hline United States & 0.422 & 0.246 & 0.398 & 0.157 & 1.223 & 10 \\
\hline Uruguay & 0.525 & 0.508 & 0.505 & -0.427 & 1.111 & 11 \\
\hline Puerto Rico & 0.365 & -0.215 & 0.539 & -0.005 & 0.684 & 12 \\
\hline Spain & 0.628 & -0.046 & 0.086 & -0.128 & 0.540 & 13 \\
\hline Argentina & 0.623 & -0.059 & 0.077 & -0.149 & 0.491 & 14 \\
\hline Slovenia & -0.049 & 0.216 & 0.319 & -0.069 & 0.418 & 15 \\
\hline Serbia and Mont. & 0.189 & -0.090 & -0.115 & 0.326 & 0.309 & 16 \\
\hline Dominican Rep. & 0.133 & -0.189 & 0.322 & 0.030 & 0.297 & 17 \\
\hline Morocco & 0.311 & -0.346 & -0.265 & 0.469 & 0.168 & 18 \\
\hline Chile & 0.235 & 0.156 & 0.239 & -0.462 & 0.167 & 19 \\
\hline Albania & 0.231 & -0.136 & -0.170 & 0.232 & 0.157 & 20 \\
\hline Bosnia and Herz. & 0.000 & 0.052 & -0.095 & 0.174 & 0.132 & 21 \\
\hline Cyprus & -0.068 & -0.067 & 0.222 & 0.017 & 0.105 & 22 \\
\hline Romania & -0.187 & -0.100 & -0.095 & 0.378 & -0.004 & 23 \\
\hline Hungary & -0.432 & -0.068 & 0.520 & -0.076 & -0.056 & 24 \\
\hline Poland & 0.135 & -0.048 & 0.342 & -0.502 & -0.073 & 25 \\
\hline Macedonia & -0.611 & 0.042 & 0.523 & -0.059 & -0.105 & 26 \\
\hline Peru & 0.317 & -0.460 & -0.082 & 0.018 & -0.207 & 27 \\
\hline Trinidad and Tob. & 0.518 & -0.715 & 0.042 & -0.061 & -0.215 & 28 \\
\hline Ethiopia & 0.192 & 0.586 & -0.868 & -0.139 & -0.228 & 29 \\
\hline Guatemala & 0.598 & -0.281 & -0.137 & -0.429 & -0.249 & 30 \\
\hline Taiwan & -0.322 & 0.068 & 0.206 & -0.213 & -0.261 & 31 \\
\hline Tanzania & -0.057 & -0.067 & -0.499 & 0.341 & -0.282 & 32 \\
\hline Georgia & 0.135 & -0.398 & -0.261 & 0.180 & -0.344 & 33 \\
\hline Azerbaijan & 0.228 & -0.218 & -0.576 & 0.171 & -0.395 & 34 \\
\hline Estonia & 0.186 & -0.483 & -0.264 & 0.109 & -0.452 & 35 \\
\hline Venezuela & -0.240 & -0.237 & 0.194 & -0.204 & -0.486 & 36 \\
\hline
\end{tabular}




\begin{tabular}{|c|c|c|c|c|c|c|}
\hline Brazil & 0.630 & -0.598 & -0.175 & -0.350 & -0.493 & 37 \\
\hline Bulgaria & 0.062 & -0.306 & -0.295 & 0.037 & -0.501 & 38 \\
\hline Burkina Faso & 0.743 & -0.535 & -0.943 & 0.231 & -0.505 & 39 \\
\hline Belarus & 0.697 & -0.660 & -0.581 & -0.010 & -0.554 & 40 \\
\hline Latvia & 0.194 & -0.608 & -0.165 & -0.018 & -0.596 & 41 \\
\hline Indonesia & -0.998 & 0.259 & 0.019 & 0.111 & -0.608 & 42 \\
\hline Slovakia & 0.027 & -0.587 & -0.159 & 0.106 & -0.613 & 43 \\
\hline Ukraine & 0.370 & -0.410 & -0.497 & -0.081 & -0.619 & 44 \\
\hline Mexico & -0.351 & 0.115 & -0.157 & -0.311 & -0.703 & 45 \\
\hline South Africa & -0.209 & -0.416 & -0.137 & -0.022 & -0.785 & 46 \\
\hline Ghana & -0.164 & -0.548 & -0.530 & 0.407 & -0.835 & 47 \\
\hline Moldova & 0.165 & -0.383 & -0.440 & -0.186 & -0.844 & 48 \\
\hline Czech Republic & -0.189 & -0.590 & -0.153 & 0.080 & -0.852 & 49 \\
\hline Viet Nam & -0.837 & 0.145 & -0.466 & 0.296 & -0.863 & 50 \\
\hline Uganda & 0.086 & -0.722 & -0.575 & 0.259 & -0.951 & 51 \\
\hline Kyrgyzstan & -0.079 & -0.284 & -0.467 & -0.177 & -1.008 & 52 \\
\hline Armenia & 0.037 & -0.395 & -0.681 & 0.030 & -1.008 & 53 \\
\hline Serbia & -0.481 & -0.170 & -0.222 & -0.142 & -1.015 & 54 \\
\hline Zimbabwe & 0.106 & -0.806 & -0.463 & 0.146 & -1.017 & 55 \\
\hline Lithuania & -0.282 & -0.344 & -0.411 & -0.081 & -1.118 & 56 \\
\hline Nigeria & -0.068 & -0.761 & -0.800 & 0.489 & -1.140 & 57 \\
\hline Russian Fed. & 0.424 & -0.924 & -0.528 & -0.262 & -1.290 & 58 \\
\hline Thailand & -1.219 & 0.353 & -0.058 & -0.387 & -1.310 & 59 \\
\hline Mali & -0.147 & -0.331 & -1.005 & 0.131 & -1.352 & 60 \\
\hline Turkey & -0.506 & -0.551 & -0.248 & -0.084 & -1.389 & 61 \\
\hline India & -1.188 & -0.158 & -0.530 & 0.441 & -1.436 & 62 \\
\hline Jordan & -2.243 & 0.190 & 0.066 & 0.408 & -1.579 & 63 \\
\hline South Korea & -0.950 & 0.216 & -0.493 & -0.381 & -1.607 & 64 \\
\hline Zambia & -0.680 & -0.391 & -0.668 & 0.012 & -1.727 & 65 \\
\hline Philippines & -0.420 & -0.482 & -0.621 & -0.273 & -1.796 & 66 \\
\hline Bangladesh & -2.890 & 0.340 & -0.716 & 0.469 & -2.797 & 67 \\
\hline Hong Kong & -3.040 & 0.281 & -0.657 & -0.225 & -3.641 & 68 \\
\hline
\end{tabular}


Table 11: Population-weighted value development indices for the Anglo-Saxon overseas democracies, the EU, Turkey, the countries of the West Balkan and the Russian Federation

\begin{tabular}{|l|c|c|c|c|c|}
\hline & $\begin{array}{c}\text { Anglo- } \\
\text { Saxon } \\
\text { overseas } \\
\text { democracies }\end{array}$ & EU & Turkey & $\begin{array}{c}\text { West- } \\
\text { Balkan }\end{array}$ & $\begin{array}{c}\text { Russian } \\
\text { Federation }\end{array}$ \\
\hline $\begin{array}{l}\text { Avoiding economic } \\
\text { permissiveness }\end{array}$ & 0.745 & 0.254 & 1.162 & -1.212 & -0.856 \\
\hline Avoiding racism & 0.465 & 0.294 & -0.506 & -0.242 & 0.424 \\
\hline $\begin{array}{l}\text { Avoiding distrust of the army and } \\
\text { the press }\end{array}$ & 0.059 & -0.308 & 0.283 & -0.352 & -0.129 \\
\hline $\begin{array}{l}\text { Avoiding the authoritarian } \\
\text { character }\end{array}$ & 0.299 & 0.237 & -0.551 & -0.083 & -0.924 \\
\hline $\begin{array}{l}\text { Tolerance and respect + post- } \\
\text { materialism }\end{array}$ & 0.430 & 0.424 & -0.248 & -0.085 & -0.528 \\
\hline $\begin{array}{l}\text { Avoiding rejection of the market } \\
\text { economy and democracy }\end{array}$ & 0.146 & -0.082 & -0.084 & 0.018 & -0.262 \\
\hline Global Value Development Index & 2.143 & 0.819 & 0.056 & -1.955 & -2.275 \\
\hline
\end{tabular}

Population weights for the West Balkan countries Albania; Bosnia and Herzegovina; Macedonia and Serbia taken from:

https://www.wko.at/Content.Node/Interessenvertretung/ZahlenDatenFakten/Statistische_Laenderprofile.html 
Graph 1: Map of global human values according to Inglehart and associates (our own adaption) and the place of Turkey on it.
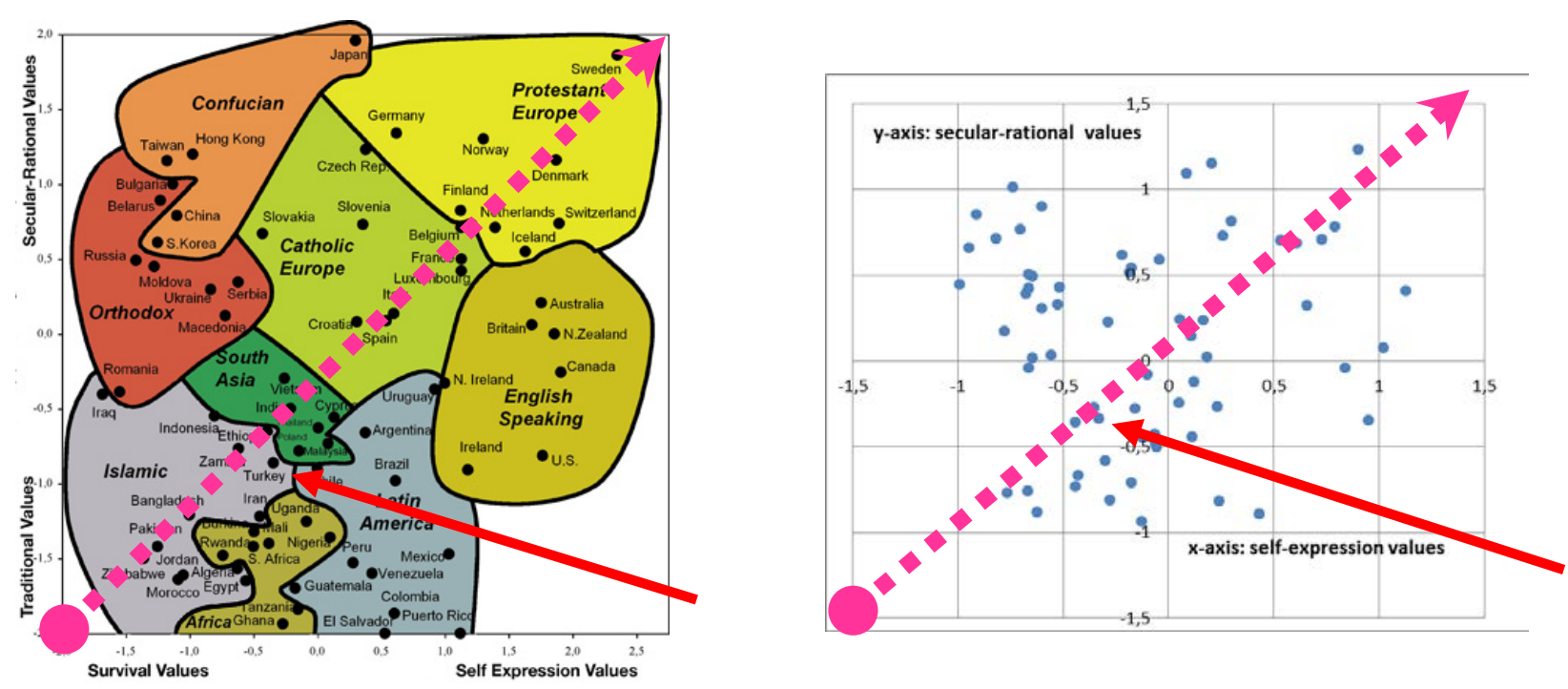

Note: Turkey: $\mathrm{x}=-0,443 ; \mathrm{y}=-0,360$. Source: adapted from Ronald Inglehart and Christian Welzel, "Changing Mass Priorities: The Link between Modernization and Democracy." Perspectives on Politics, June 2010 (Vol 8, No. 2) page 554. Graph 1 is the latest published version of the Inglehart/Welzel map. 


\section{Graph 2: Screeplot for our factor analysis}

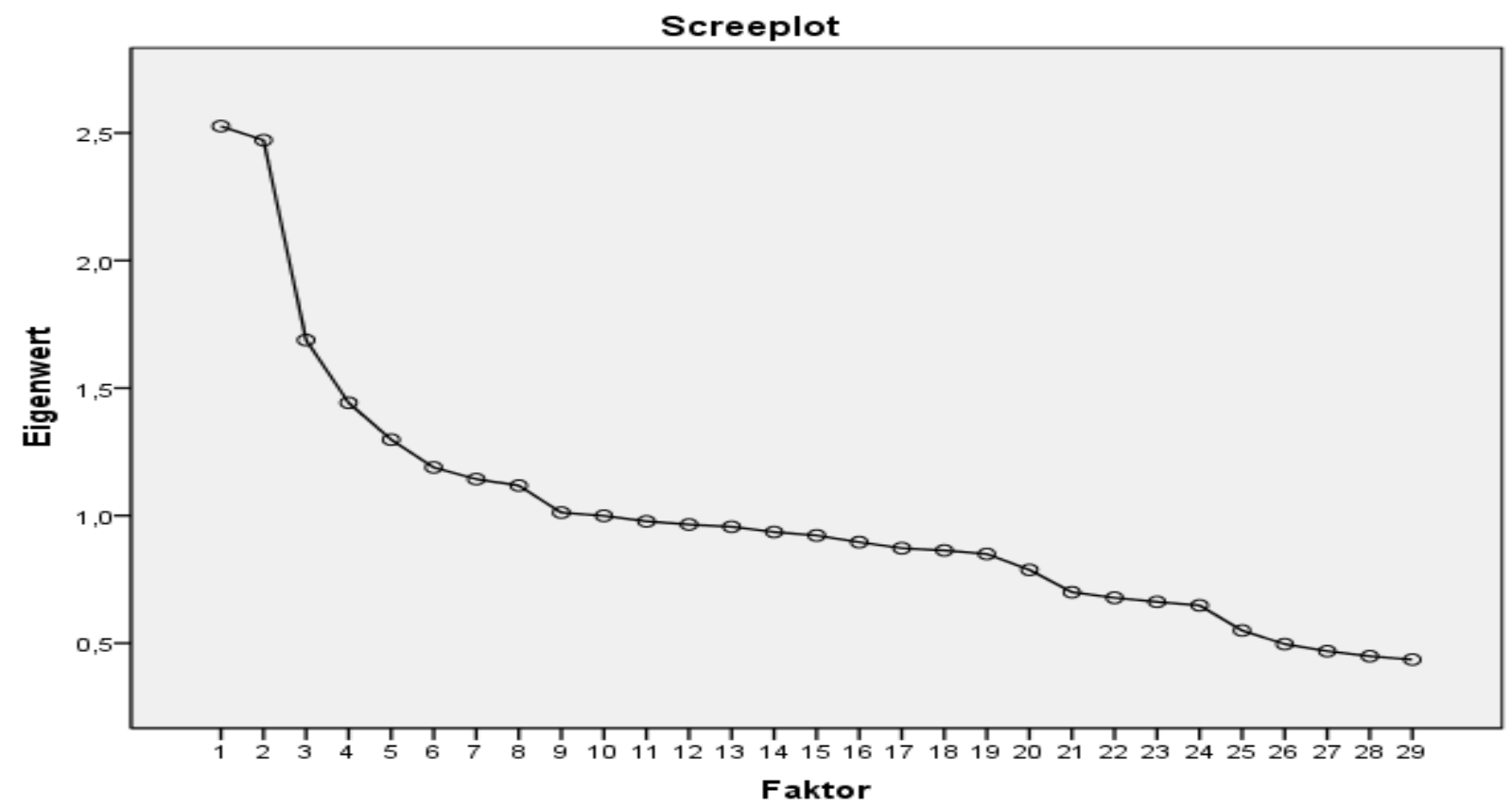

\begin{tabular}{|l|c|c|c|}
\hline Indicators & Eigenvalue & $\begin{array}{c}\text { \% of variance } \\
\text { explained }\end{array}$ & $\begin{array}{c}\text { Cumulated } \\
\text { percentage }\end{array}$ \\
\hline Economic permissiveness & 2.526 & 8.711 & 8.711 \\
\hline Traditional religion & 2.472 & 8.523 & 17.234 \\
\hline Racism & 1.688 & 5.822 & 23.056 \\
\hline Higher education of the younger generation & 1.442 & 4.974 & 28.029 \\
\hline Distrust of the army and the press & 1.298 & 4.475 & 32.504 \\
\hline Authoritarian character & 1.189 & 4.099 & 36.604 \\
\hline Tolerance and respect & 1.143 & 3.942 & 40.545 \\
\hline The 'ego' company & 1.118 & 3.854 & 44.399 \\
\hline Rejection of the market economy and democracy & 1.012 & 3.489 & 47.888 \\
\hline
\end{tabular}


Graph 3: Liberal values as a drivers of "effective democracy”
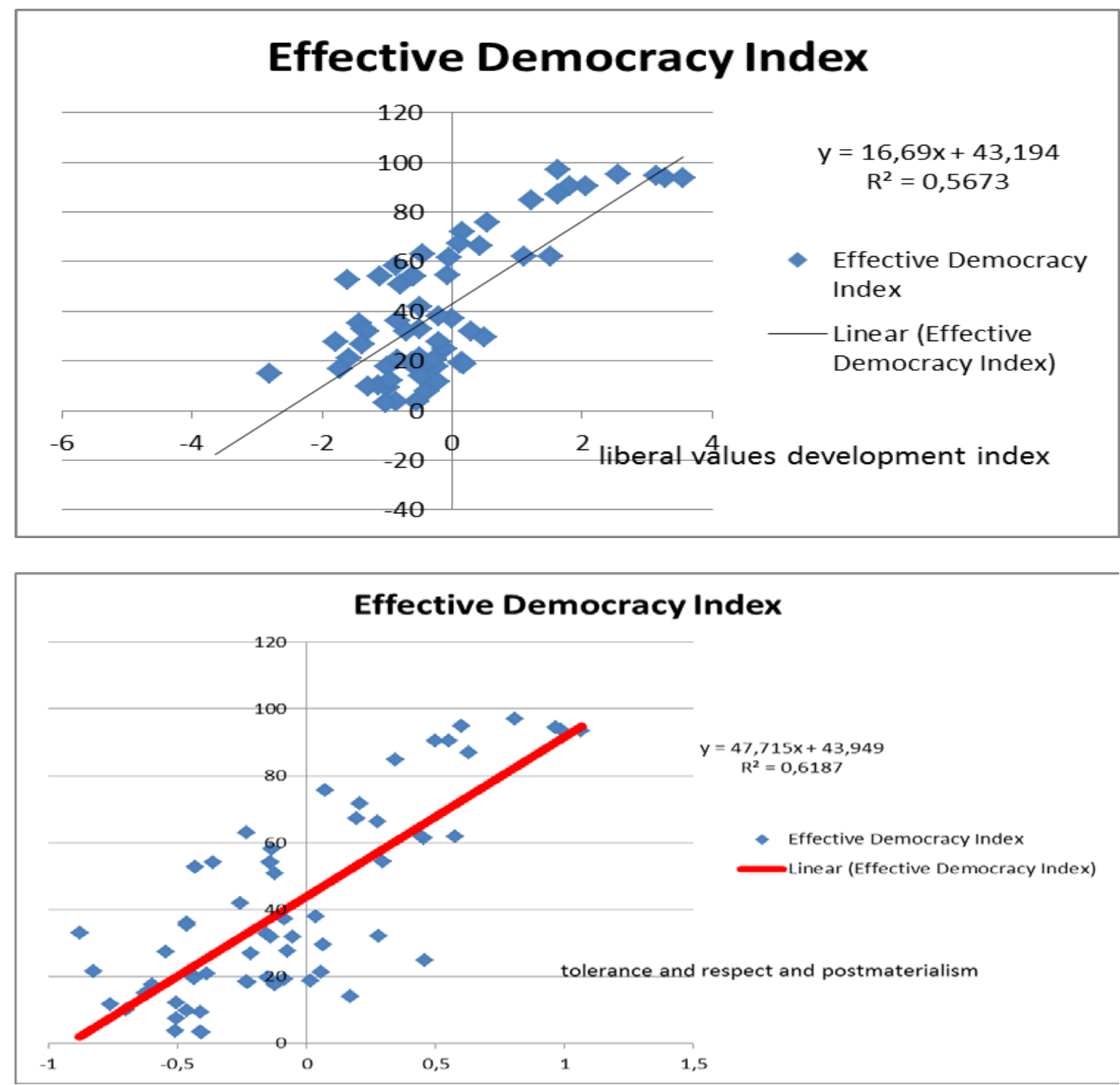

Note: the evidence from the relationship between our liberal values development index and the tolerance and respect and postmaterialism factor on the one hand and effective democracy on the other hand.

Source: Our own calculations from Alexander, Inglehart and Welzel (2012) and the results of this work. 


\section{Graph 4: Population-weigthed value structures for selected countries and country groups.}
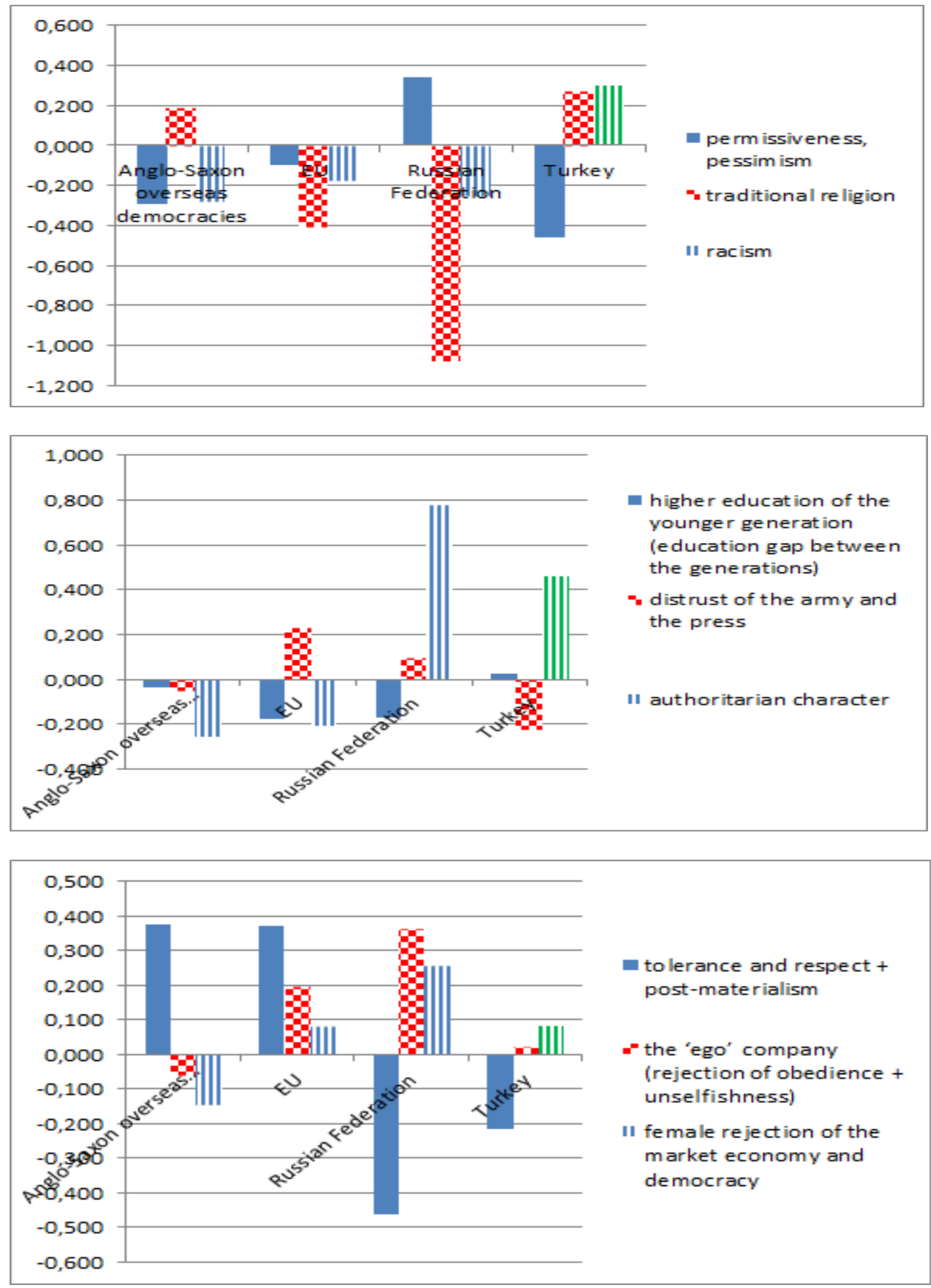

Notes: Anglo-Saxon overseas democracies (Australia, Canada, New Zealand, United States) and the EU with available data (Bulgaria; Cyprus; Czech Republic; Estonia; Finland; Germany; Hungary; Italy; Latvia; Lithuania; Poland; Romania; Slovakia; Slovenia; Spain; Sweden) 
Map 1: Inglehart: Secular Values. Data from the WVS waves 1-4

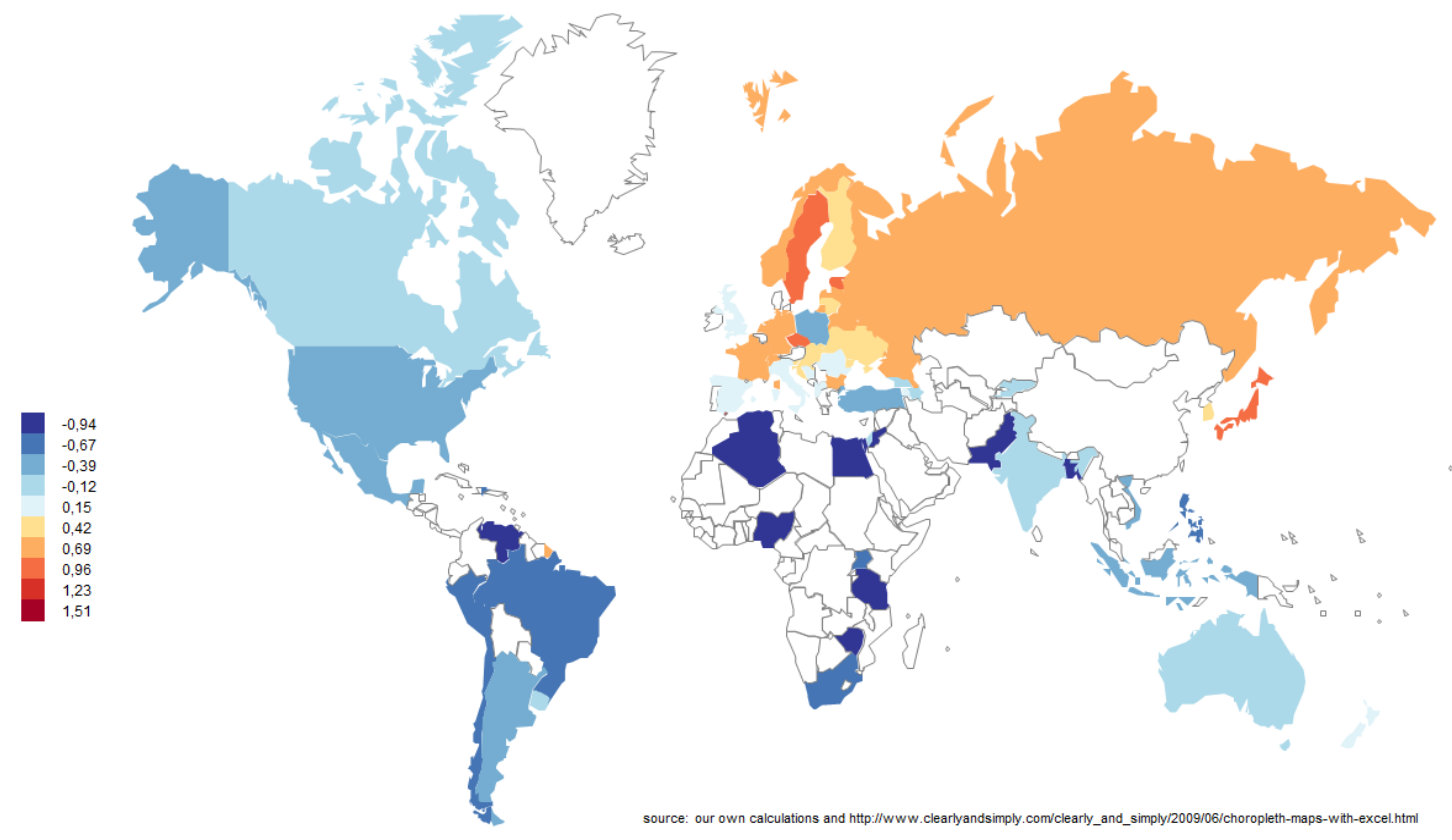

Map 2: Inglehart: Self-Expression Values. Data from the WVS waves 1-4






\section{Map 3: Economic permissiveness}

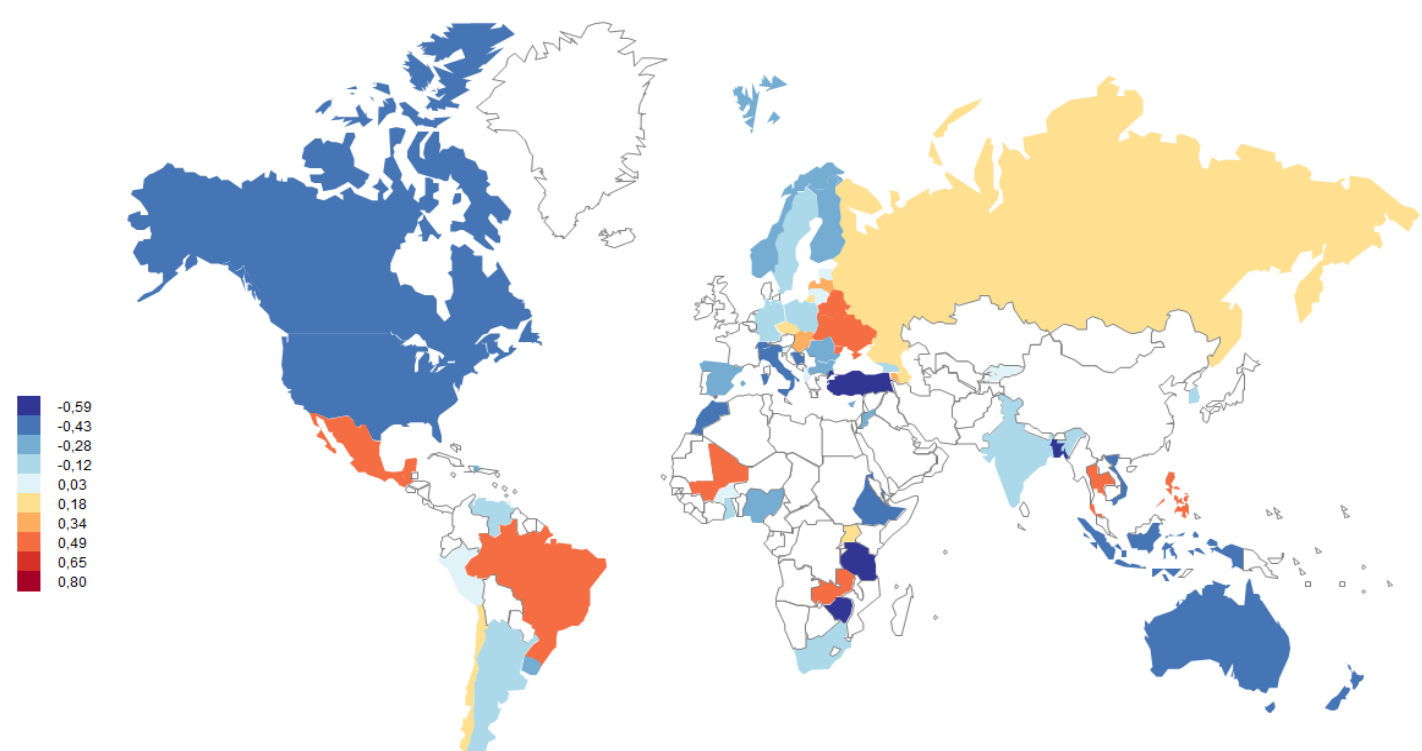

Justifiable: cheating on taxes

Justifiable: avoiding a fare on public transport

Justifiable: someone accepting a bribe

Justifiable: claiming government benefits

\section{Map 4: Traditional religion}

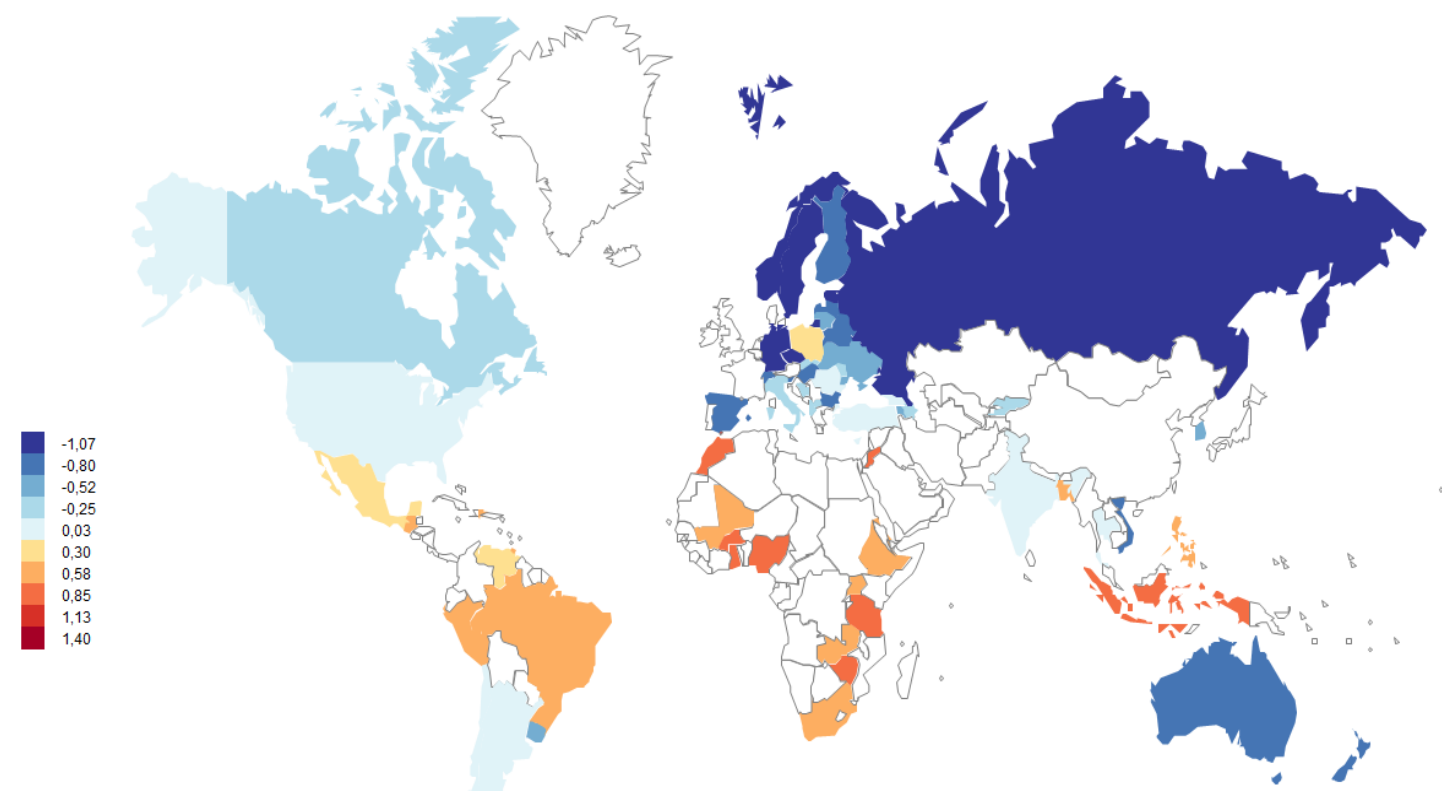

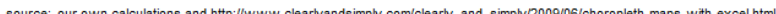

How important is God in your life

Important child qualities: religious faith

Negative loading: never attend religious services 


\section{Map 5: Racism}



Map 6: Generational education gaps, a growing acceptance of female higher education and the rejection of thrift

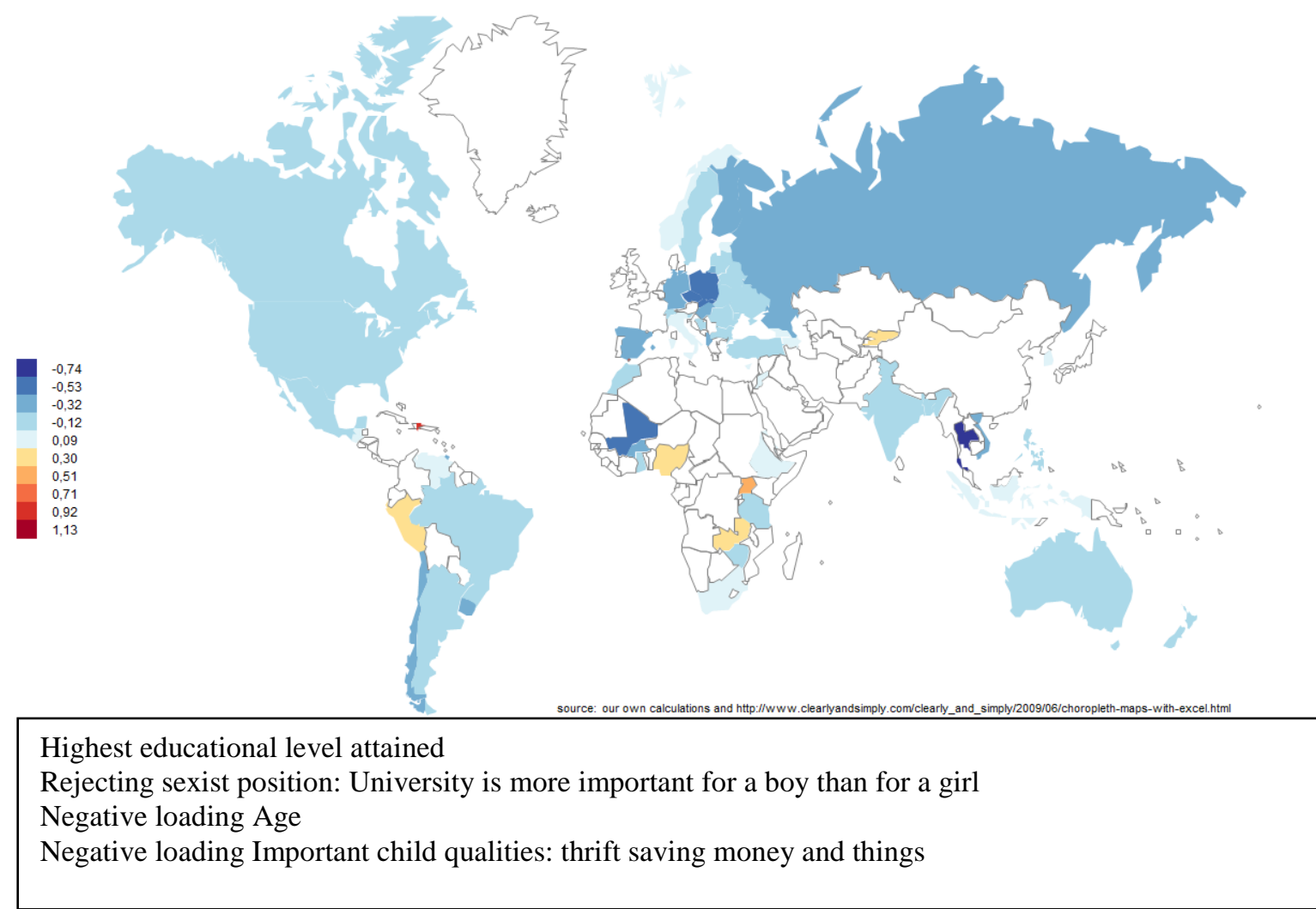




\section{Map 7: Distrust of the army and the press}

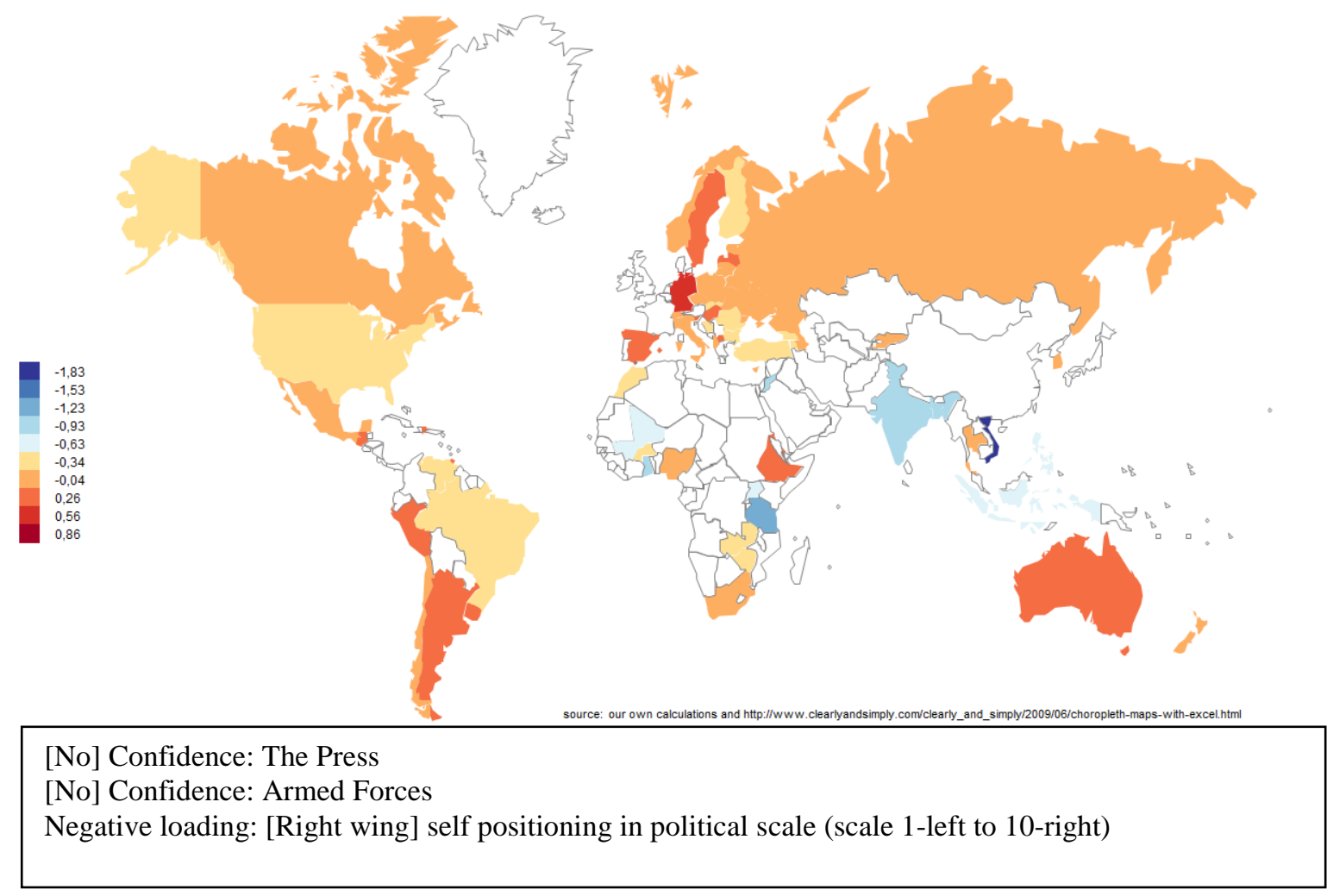

\section{Map 8: Authoritarian character}



Lack of social capital (Most people can be trusted [highest numerical value: you just can't be too careful])

Important child qualities: hard work

Important child qualities: obedience

Negative loading: Important child qualities: imagination

Negative loading: Important child qualities: independence 


\section{Map 9: Tolerance and respect + post-materialism}

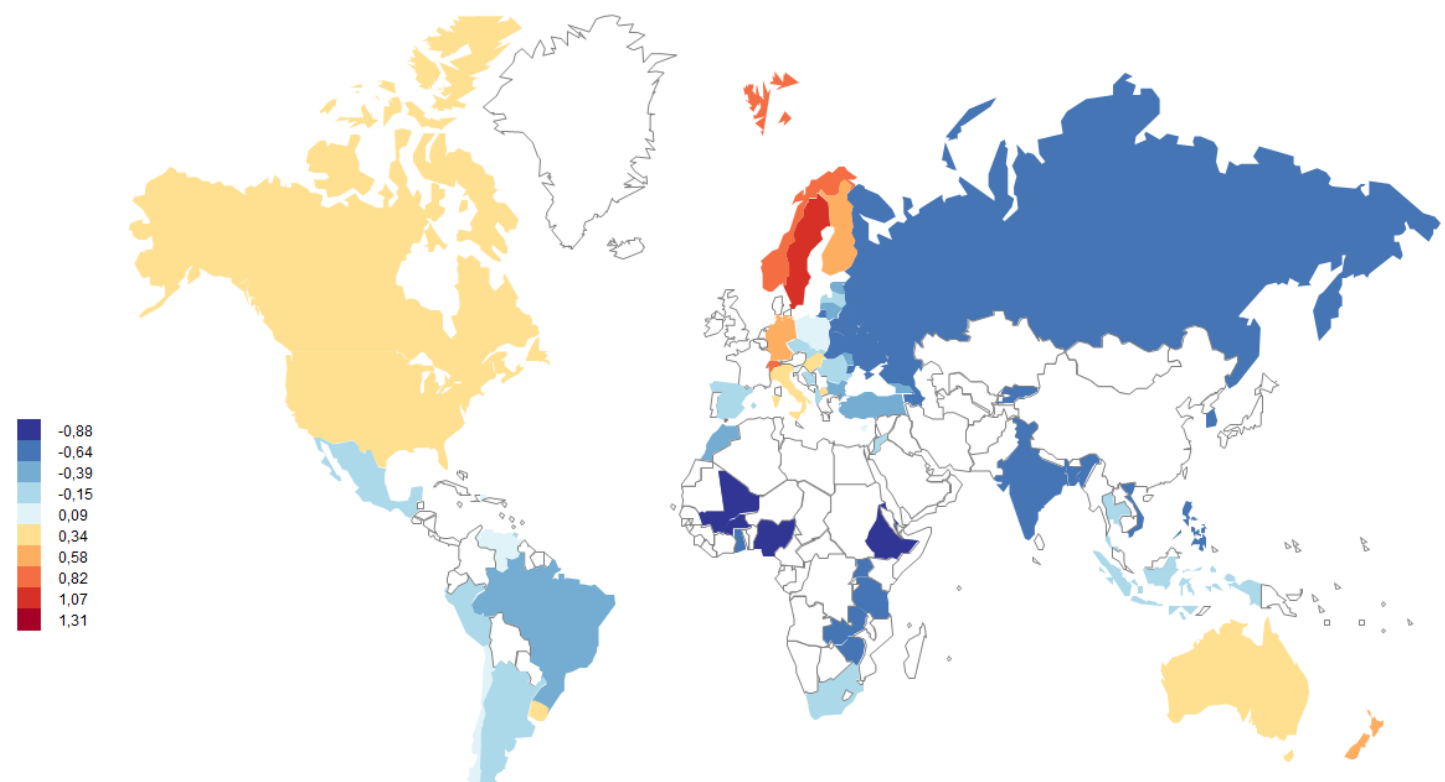

source; our own calculations and http///www_clearlyandsimply_com/clearly_and_simply/2009/06/choropleth-maps-with-excel hth

Important child qualities: tolerance and respect for other people

Important child qualities: feeling of responsibility

Rejecting sexist position: University is more important for a boy than for a girl

Negative loading: Important child qualities: hard work

\section{Map 10: The 'ego' company}

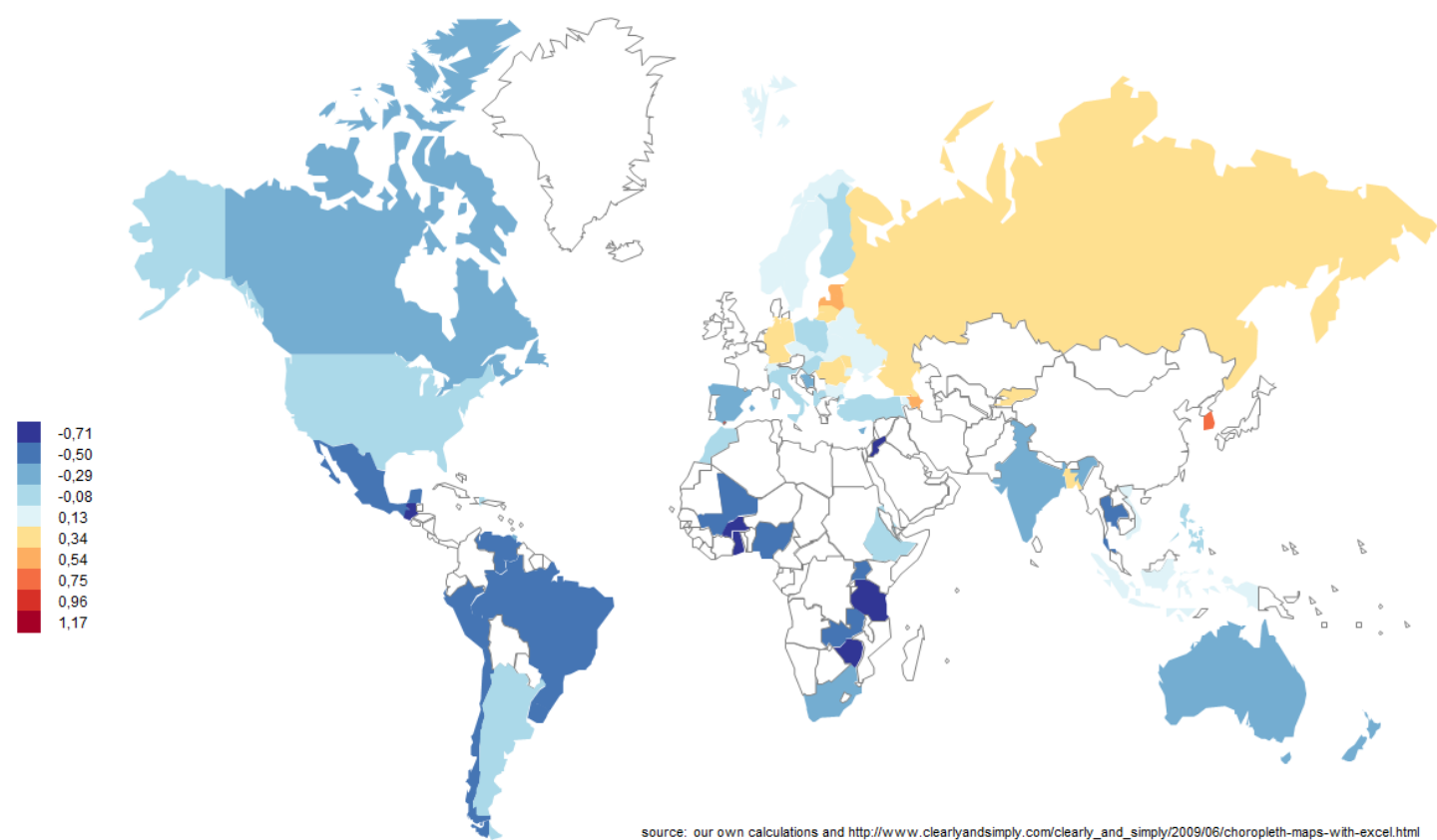

Important child qualities: feeling of responsibility

Important child qualities: independence

Negative loading: Important child qualities: unselfishness

Negative loading: Important child qualities: obedience 


\section{Map 11: Rejection of the market economy and democracy}

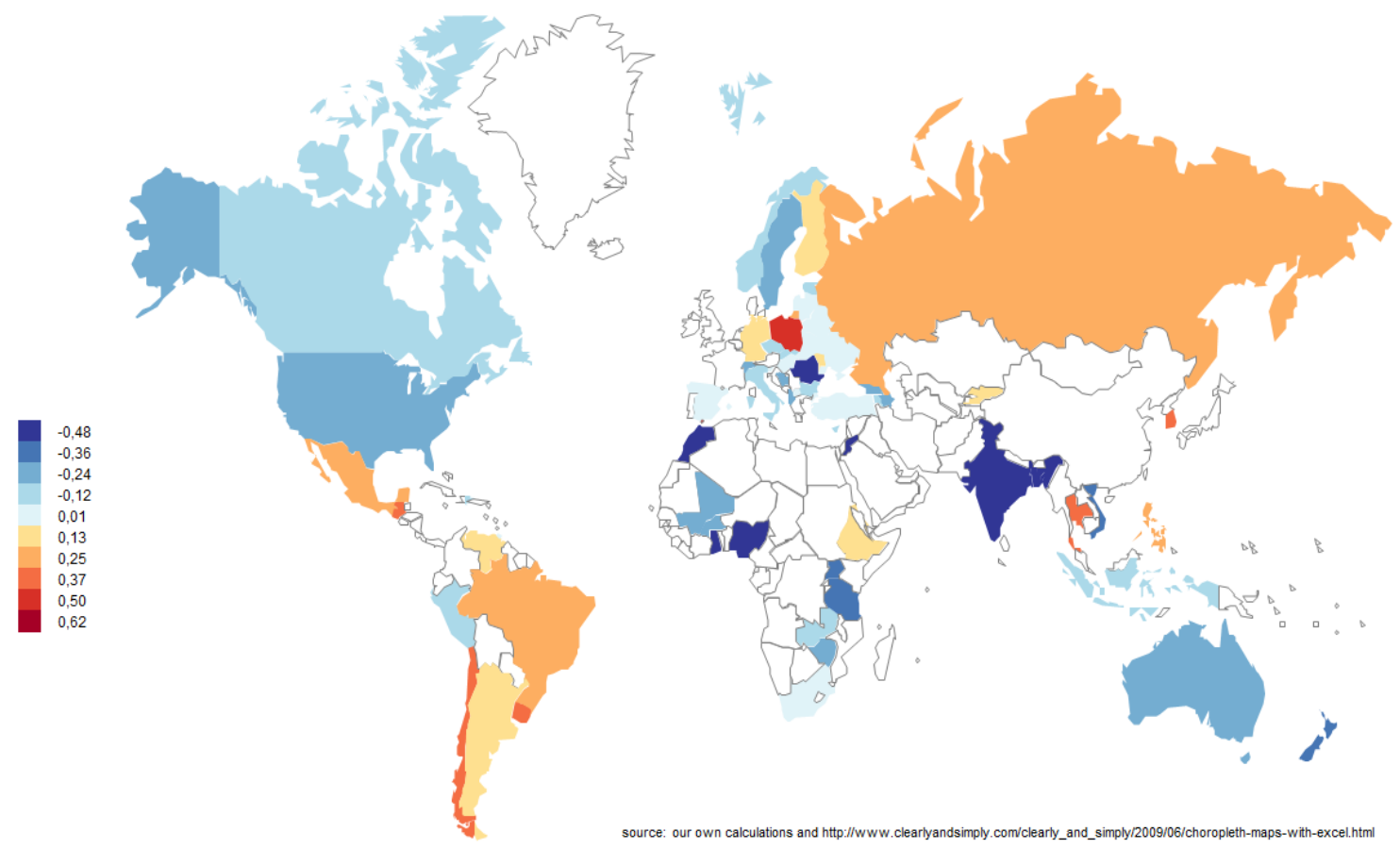

Sex (Gender) [in multivariate analysis: female] (1=male; $2=$ female)

Competition good or harmful

Political system: (It’s very bad] having a democratic political system

\section{Map 12: Combined global value development index}

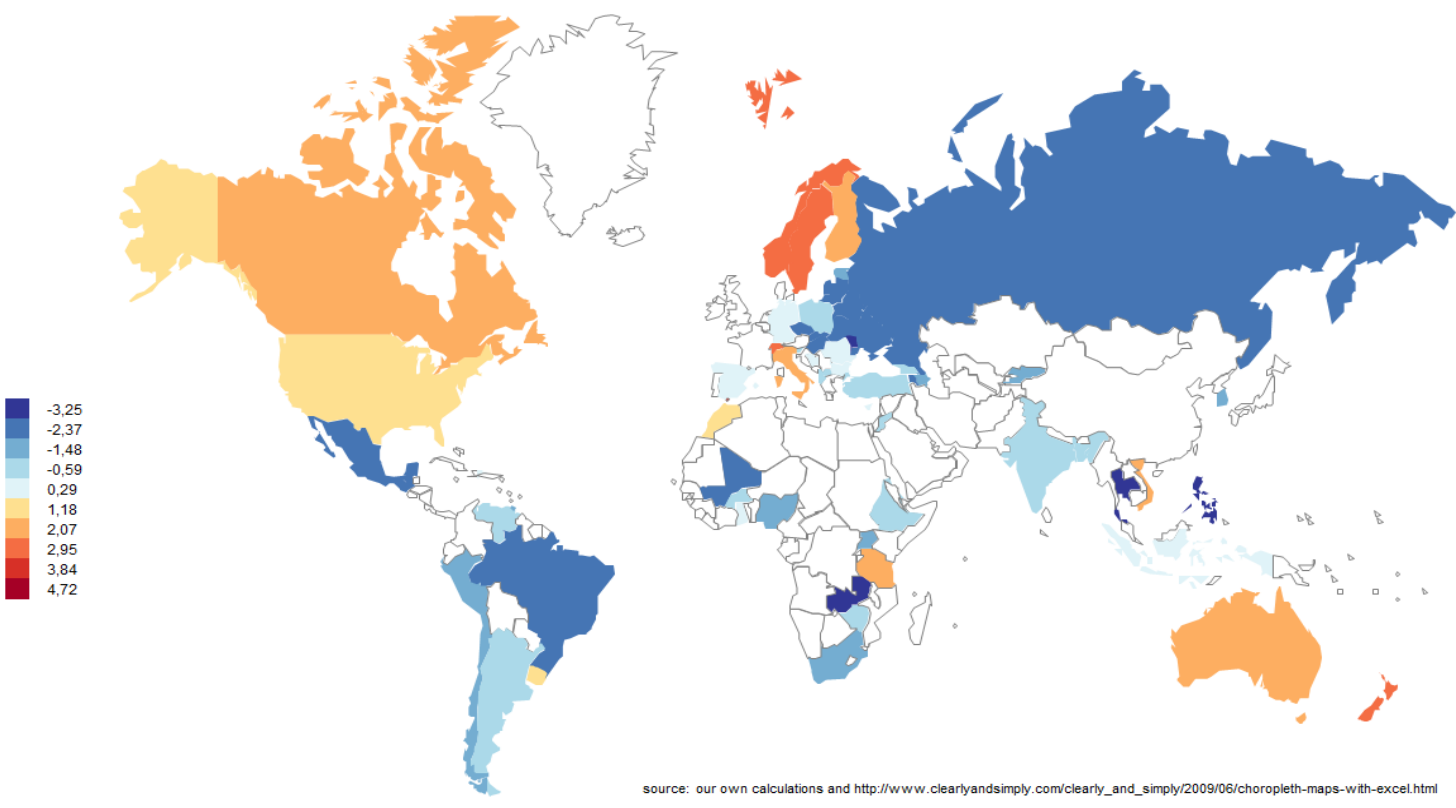

Note: avoiding permissiveness, racism, distrust of the army and the press, authoritarian character, rejection of the market economy and democracy; and practicing the values of tolerance and respect (weighted by the Eigenvalues of the promax factor analytical model) 